Poznańskie Studia Teologiczne 30(2016), s. 7-56.

doi: $10.14746 /$ pst.2016.30.01

Fr. Emery de Gaál, Ph.D. ${ }^{1}$

University of St. Mary of the Lake, Mundelein Seminary

\title{
Revelation as the Thou of Jesus Christ Joseph Ratzinger's/Pope Benedict XVI's Contribution to a deeper Understanding of Revelation
}

$18^{\text {th }}$ century Deism and subsequent Positivism have the Church deeper expound on the nature of divine revelation at the I. and II. Vatican Councils. Joseph Ratzinger/Pope Benedict XVI played in this process a pivotal role.

\section{Revelation and the early Ratzinger}

\subsection{Bonaventure's foundational Influence}

Though Ratzinger's post-doctoral Habilitationsschrift ${ }^{2}$ entitled The Theology of History in St. Bonaventure was directed to examining such concepts as history, metaphysics, and eschatology, it highlights his understanding of revelation. Ratzinger's theology of revelation begins with his study of Bonaventure's (1217-1274) "spiritual understanding of the Scripture."3

\footnotetext{
${ }^{1}$ V.D., Dipl. Theol. University of Munich (Röm 3,21-31 als paulinischer Austrag des bereits als Traditionsgut vorgefundenen Rechtfertigungsgedankens); Ph.D. in Systematic Theology, Duquesne University. Associate Pastor, Instructor, Member of Catholic-Protestant Ecumenical Dialogue in Nuremberg, Germany, Author of The Art of Equanimity: A Study on the Theological Hermeneutics of Saint Anselm of Canterbury and The Theology of Pope Benedict XVI - The Christocentric Shift. Contributes articles and book reviews to a number of academic journals. Member of the American Academy of Religion, American Benedictine Academy, Catholic Theological Society of America, Medieval Academy of America, Société Internationale des Mediévistes, and The International Mariological Society.

2 J. Ratzinger, Milestones Memories 1927-1977, trans. E. Leiva-Merikakis, San Francisco 2003, p. 103.

${ }^{3}$ For Bonaventure a "Spiritual understanding of scripture involved 'manifold divine wisdom' which consists in grasping the three-fold spiritual sense of Scripture - the allegorical, the anagogical and the tropological" - J. Ratzinger, The Theology of History in St. Bonaventure, trans. Z. Hayes, Chicago [USA, Illinois] 1971, p. 62.
} 
For Ratzinger, the point of departure to understanding Bonaventure's concept of revelation requires ${ }^{4}$ penetrating the Collationes in Hexaëmeron. ${ }^{5}$ Indeed, prominent Bonaventure scholar Colt Anderson has stated that reading the Collationes "is akin to entering another world drawn along entirely different premises than our own."

Collationes or lectures on Hexaëmeron were presented by Bonaventure to his fellow Franciscan brothers in the University of Paris during summer of 1273. Previously withdrawn into solitude, Bonaventure had experienced the spiritual world of Francis of Assisi. Again entering Paris University as a professor to lecture, Ratzinger says of Bonaventure: "He came back as an outsider to point out the limits of science from the perspective of faith."

Interpreting the Collationes is difficult: during the thirteenth century, the term "collatio" referred to an afternoon sermon, but Bonaventure delivered them at the university in an academic style. In addition, the original manuscript of Bonaventure's Collations is not available; only notes of the listeners are extant. Another difficulty was the official reportatio: "This text would have been read and approved by Bonaventure; however there was also another recension, published by Ferdinand Delorme, which often varies significantly from the official text." ${ }^{\text {A }}$ At the time, Bonaventure had not mentioned the names of those who were connected to different problems, but expressed them symbolically. ${ }^{9}$ These reasons made it difficult for those interpreting Bonaventure's Collationes.

The Hexaëmeron involved internal and external struggles related to its mission and preaching. Moreover, Bonaventure also prepared his Franciscan brothers for the Second Council of Lyons (1274) by exhorting them to obedience to the bishops and uphold unity and Christian truth among themselves. ${ }^{10}$ While Ratzinger's thesis does not treat every issue the Hexaëmeron addressed, it treats the themes directly connected to his understanding of revelation.

\footnotetext{
${ }^{4}$ New Catholic Encyclopedia, Washington, DC 2003, s.v. "Hexaemeron" by Z. Hayes. The term hexaëmeron derived from two Greek words, the numeral "six" and the noun "day," which refers to and interprets the book of Genesis where God's creative work is completed in six days, followed by the seventh day of the Sabbath rest and connecting these to the six stages of salvation history.

${ }^{5}$ J. Ratzinger, The Theology of History in St. Bonaventure, 1-3. Bonaventure, after serving as a professor at Paris, was called to replace the General, John of Parma as the seventh successor of St. Francis. After he withdrew to solitude on Mount Alverna in 1259, he allowed himself to be drawn more deeply into the spiritual world of Francis in whose place he stood. From then on, he called Francis a "Christ-image of the Middle Ages." After ten years he returned to the same university to teach, but now as an altogether transformed person, who pointed out the limits of science from the perspective of faith. It is in this context that we need to understand his Collationes in Hexaëmeron written in 1273.

${ }^{6}$ C. Anderson, A Call to Piety: St. Bonaventure's Collations on the Six Days, Quincy [USA, Illinois], vi.

${ }^{7}$ J. Ratzinger, The Theology of History in St. Bonaventure, 3.

${ }^{8}$ C. Anderson, A Call to Piety: St. Bonaventure's Collations on the six Days, vi.

${ }^{9}$ Ibid., vii.
} 
Bonaventure preached the Hexaëmeron to his Franciscan brothers to preserve and hold to true Christian wisdom amidst the intellectual "aberrations" of his time. ${ }^{11}$ For the Franciscan theologian, the attainment of Christian wisdom was never unrelated to the concrete historical situation. Therefore, Ratzinger noted, "The development of the ideal of wisdom naturally grows into a treatment of the theology of history." ${ }^{\prime 2}$ In the treatment of theology of history, Bonaventure offered a new theory of scriptural exegesis that gave more importance to the historical character of the scriptural statements - how very "modern."13

In his study The Theology of History in St. Bonaventure, Ratzinger observes Bonaventure's scriptural exegesis is multilayered. The first layer consisted of the Spiritualis intelligentia, which understands Scripture in its allegorical or tropological meaning; secondly, there is the figurae sacramentales that focus on Christ as the key to understanding scripture; third, multiformes theoriae, which give rise to many theories that emerge from Scripture; the fullness of which God alone can grasp in his knowledge. Bonaventure applied the analogy of the "seed" to illustrate the manifold theory:

From one single seed, entire forests grow up; and they in turn bring forth innumerable seeds, so it happens that innumerable theories can rise from Scripture which only God can grasp in His knowledge. As new seeds come from plants, so also new theories and new meaning come from Scripture. ${ }^{14}$

Ratzinger did not find the complete meaning of "theories" in Bonaventure's work. However, Ratzinger interprets: "[Theories] are intimations about future times found in Scripture. Scripture points to the future... The whole of history develops in the broken line of meaning in which, that which is to come may be grasped in the present on the basis of the past" 15 Ratzinger understood theories as prophesies about the future; in other words, the knowledge of the history of salvation enlightens our understanding of the future.

\footnotetext{
${ }^{10}$ Ibid., xv.

11 "Bonaventure was involved in at least three identifiable controversies in the late 1260 s and early 1270s. The first controversy had to do with the Latin Averroists and centered upon their claims for the legitimacy of an independent philosophy... The second controversy was over the status of the mendicant orders in the universities and over the value of the principle poverty. The third controversy involved the Franciscan Order internally and externally and was tied to the polemics of the Mendicant and Averroist Controversies." - C. Colt Anderson, A Call to Piety: St. Bonaventure's Collations on the six Days, vii.

${ }^{12}$ Bonaventure's work "distinguishes six levels of knowledge which are interpreted allegorically in relation to the six days of the creation account. At the same time, the six periods of salvation history are related to the six days of creation." - J. Ratzinger, The Theology of History in St. Bonaventure, 6 .

${ }^{13}$ Ibid., 7.

${ }^{14}$ Ibid.

${ }^{15}$ Ibid., 8 .
} 
Bonaventure believed in the progress of the understanding of meaning in Scripture as comprises the mysteries of God. For him "Scripture is closed objectively," 16 but the seed of understanding grows in every age. What the Fathers of the Church could not have known because of the indefinite future, is known to the next generation due to the access they have to history. Future generations, in the same way, will disclose the ideas of the present age, which are unknown now, because the present time turns into history for future generations. In that sense, it can be said we have a more enlightened understanding of Scripture due to historical events. Therefore, because of the progress in understanding the Scripture, new knowledge is obtained. For Bonaventure, theology is the interpretation of Scripture in the Augustinian light of the past, present and future. Thus, the exegesis of Scripture becomes the theology of history. ${ }^{17}$

Bonaventure observed continuity and progress in the history of salvation. $\mathrm{He}$ believed in "inner-worldly and inner-historical messianic hope." $18 \mathrm{He}$ is convinced that through Christ everything that was said in the Old Testament is fulfilled. He cites a prophecy from Isaiah 2:4 to affirm his stance: "Nations shall not lift up sword against nation, nor shall they learn war anymore." He did not witness this Scripture passage being fulfilled fully in his life-time. ${ }^{19}$ Hence, Bonaventure believes in inner-historical, messianic hope. Nevertheless, Ratzinger foresaw a theological problem in believing in a new salvation history within the limits of the present era. Ratzinger states:

Bonaventure raises a new, inner-worldly, inner-historical messianic hope. He rejects the view that with Christ the highest degree of inner-historical fulfillment is already realized so that there is nothing left but an eschatological hope for that which lies beyond all history. Bonaventure believes in a new salvation in history, within the limits of this time. This is a very significant shift in the understanding of history, and must be seen as the central historico-theological problem of Hexaemeron. ${ }^{20}$

According to Bonaventure, even after the coming of Christ into this world, not everything is perfected. Evil things continue to occur in the world. Ratzinger noted that "inner worldly, inner messianic hope of Bonaventure became clearer in the further reading of Hexaëmeron. However, Ratzinger understood Bonaventure's inner messianic hope in terms of the mission of the Church. The Church carries out Christ's mission until the end time, fulfilling the prophecies contained in Scripture. ${ }^{21}$

Ratzinger sketched the meaning of revelation from his reading of the Hexaëmeron. Revelation is "the unveiling of the hidden or mystical meaning of the

\footnotetext{
${ }^{16}$ Ibid., 9.

${ }^{17}$ Ibid.

${ }^{18}$ Ibid., 13.

${ }^{19}$ Ibid.

${ }^{20}$ Ibid., 14.

${ }^{21}$ Ibid.
} 
scriptures." 22 Bonaventure analyzed the three directions of the unveiling of the hidden mysteries in particular. The first direction of revelation "unveils the future," the second direction of revelation "unveils the hidden mystical meaning" of scriptures and the third direction "unveils the imageless divine reality." 23

Ratzinger detects a tension between the historical and theological understanding of the concept of revelation and the unveiling of the hidden mysteries contained in Scripture. He notes:

As far as I can see, at no time does Bonaventure refer to the Scriptures themselves as 'revelation.' He speaks of revelare and revelata primarily when a particular understanding of Scripture is involved, namely that 'manifold divine wisdom' which consists in grasping the three-fold spiritual sense of Scripture - the allegorical, the anagogical and the tropological. ${ }^{24}$

One needs the "manifold divine wisdom" in order to understand what God has revealed in Scripture. It involves allegorical, anagogical and tropological understandings of Scripture. ${ }^{25}$ Scripture is purely a book if it is not understood in a dynamic, spiritual sense that grows with the reader. For Bonaventure, "manifold divine wisdom" is considered to be the spiritual understating of Scripture.

Bonaventure used the analogy of Jesus' changing water into wine at Cana (Jn 2:1-12) to explain how mere words in Scripture are changed into the words of life. Scripture is like water, which is to be changed into wine through its in concreto spiritual understanding. Without the aid of the Holy Spirit, biblical books could be understood merely from a literary point of view. But Scripture is not just a set of documents or books, but rather must become life-giving words through faith: a personal transformation on part of the addressee, which comes about by the work of the Holy Spirit. ${ }^{26}$

In order to understand Scripture spiritually, Bonaventure encouraged his Franciscan brothers to seek the wisdom that comes through divine help. The aim of Christian learning is wisdom, which is obtained solely through Christ-like holiness; not through learning alone. Such divine-human encounter Bonaventure presents as four stages of wisdom in his Hexaëmeron: "sapientia uniformis," "sapientia multiformis," "sapientia omniformis," and "sapientia nulliformis." 27

Sapientia uniformis is concerned with the knowledge of the laws: the Supreme Soul must be worshipped, Truth must be believed, and the Supreme Good must be loved and accepted. These laws are inscribed in the first tablet of the Ten Commandments and they guide the human intellect. Knowledge of these
${ }^{22}$ Ibid.
${ }^{23}$ Ibid., 58f.
${ }^{24}$ Ibid., 62.
${ }^{25}$ Ibid., 63.
${ }^{26}$ Ibid.
${ }^{27}$ Ibid., $59 f$. 
laws is connected to philosophy. They enable a person to march toward God; yet God is never fully comprehended with this kind of wisdom. Divine light is not accessible to such wisdom. ${ }^{28}$

The second type of knowledge is multiformis, which takes over Sapientia uniformis. The multiform face of wisdom is manifested in the mysteries of Scripture. It enables a person to unveil Scripture's deeper meaning. Paul considered himself a teacher of such wisdom, which was revealed by the Holy Spirit (Eph 3: 8-10): "To me, the very least of all the holy ones, this grace was given, to preach to the Gentiles... and bring to light what is the plan of the mystery hidden from ages past in God who created all things." This kind of wisdom is revealed to the simple and humble people ("simplex et idiota") and is veiled to the eyes of the impure and learned. It echoes the wisdom of the little ones in the Gospel (Mt 11:25): "I give praise to you, Father, Lord of heaven and earth, for although you have hidden these things from the wise and the learned you have revealed them to the childlike." 29 This concept of spiritual understanding as expressed here is the essence of sapientia multiformis.

The third face is omniformis sapientia, which discovers the reflection and hand of God in all created things. It recognizes the vestiges of the Holy Trinity in creation. Creation has some traces of the Trinity, and therefore, creation reveals God to some degree. It is said in the scriptures "Ever since the creation of the world, his invisible attributes of eternal power and divinity have been able to be understood and perceived in what he has made" (Rom 1:19-20). Creation is like a book that needs interpretation in order to be understood. According to Bonaventure, Solomon symbolized this sort of wisdom. The philosophers have the same kind of wisdom, but they remain within the order of creation and do not progress towards God, who is the author of creation. Omniform wisdom remains within the created order, but never transcends it. Wisdom should lead created things to the creator, God Himself. ${ }^{30}$ Advancement occurs from one level of knowledge to another. The final stage of wisdom is "sapientia nulliformis." One who possesses this sort of wisdom approaches the mystery in silence. Ratzinger described that with formless wisdom, "the mystic approaches in silence to the very threshold of the mystery of the eternal God in the night of the intellect whose light is extinguished at such heights. ${ }^{\prime 31}$ Bonaventure believed that wisdom of this kind was shared by Paul with Timothy but it is not generally accessible. Bonaventure maintained this on the basis of the passage: "the wisdom of the Lord is hidden to the rulers who are passing away" (1 Cor 2:6-10). It is obvious in the Hexaëmeron that for Bonaventure, the highest form of wisdom is attainable only

\footnotetext{
${ }^{28}$ Ibid., 60.

${ }^{29}$ Ibid., 60f.

${ }^{30}$ Ibid.

${ }^{31}$ Ibid., 61.
} 
through personal holiness and humility. The first three stages of wisdom are not minimized, because they are all part of the process of attaining to the highest wisdom, that of formless wisdom. It bears repeating that the context of these Collationes is significant: one must remember that Bonaventure was giving spiritual instruction to his confrères, after having profoundly experienced the spiritual world of Francis. ${ }^{32}$ Hence, one can easily notice the priority Bonaventure places on spirituality and the regular practice of contemplation in the Franciscan Order as indispensable heuristic means to attaining the authentic interpretation of the mysteries of God in Scripture.

\subsection{The Limitations of Bonaventure as regards Revelation}

Ratzinger observed the differences in understanding the concept of revelation between Bonaventure and modern theology. Ratzinger states that "Bonaventure did not know the question concerning the nature of revelation in the same sense in which it is treated by our current fundamental theology in the tract, $D e$ revelatione." 33 According and significantly to Ratzinger, "Bonaventure does not treat 'revelation' but 'revelations." ${ }^{34}$ Bonaventure considered individual revelations in history, those written in the scriptures, such as, God revealing His name to Moses. But he did not treat the nature of revelation, which is behind all individual revelations. Ratzinger argued that individual revelations can be repeated, but the public revelation of Christ, which is behind all other individual revelations, cannot be repeated. In Ratzinger's analysis, Bonaventure failed to note the different processes of revelations which could be repeated time and again by God to the individual. Bonaventure did not reflect much on the unique revelation of God, the revelation in and through Christ. Bonaventure focused more on the human desire for and approach to God instead of God's approach to human beings. In chapter two Ratzinger takes another significant step toward the concept of revelation in Christ, going beyond Bonaventure's notion of revelation. ${ }^{35}$

Ratzinger opined the concepts that are used by Bonaventure in understanding revelation such as inspiratio, manifestatio, and apertio are not comparable with the concepts used in modern theology. He argued that the understanding of the concepts of revelation have developed since the time of Bonaventure. Ratzinger highlights the importance of Christ in revelation over and above any other individual revelations in the history of salvation. ${ }^{36}$

\footnotetext{
${ }^{32}$ Ibid., 62.

${ }^{33}$ Ibid., 57.

${ }^{34}$ Ibid.

${ }^{35}$ Ibid., $57 f$.

${ }^{36}$ Ibid.
} 


\subsection{Revelation and Inspiration}

Bonaventure used the concepts, revelatio and inspiratio interchangeably, as both are actuated by the Holy Spirit. For Bonaventure, the three stages of visions inspired by the Holy Spirit follow; first, visio corporalis which is the physical process of sight; second, visio spiritualis, which is a vision that enables the person to have inner strength for imagination and understanding; third, visio intellectualis, which is a vision that enables one to see the hidden truth with the illumination of the Holy Spirit. In conformity with Bonaventure, Ratzinger affirms that one can speak of revelation only in terms of visio intellectualis. This kind of vision was granted only to a few people like Paul and the evangelists. The deeper meaning of the scriptures is attained not according to individual whims, but according to the writings of the Church Fathers and approved theologians, who passed it on and explained it with great intensity. Some fundamental lines of Scripture are handed on to the faithful; the faithful in turn make an effort to accept them in faith. Sacred Scripture may remain merely an at random collection of books if not understood spiritually with the eyes of faith. One should read Scripture along with the Fathers of the Church in order to deepen one's understanding of Scripture. ${ }^{37}$

Theology plays an important role in the understanding of scriptures. Scripture in its fullest sense is theology. Ratzinger states: "Bonaventure refers to the theologian as the revelator absconditorum and to theology as the corresponding revelatio absconditorum." ${ }^{38}$ Hence, according to Bonaventure, the task of the theologian is to understand the inner meaning of the scriptures and present it to the faithful.

Ratzinger believed that only through the Church's mediatory role can Scripture be elevated ever again to revelation. An individual cannot claim it either by study or by personal effort. This is where Ratzinger gives importance to the Magisterium of the Church and tradition in understanding the scriptures and interpreting them. Such understanding allows the later Lutheran notion of sola scriptura no place. Significantly, nowhere in Scripture is it written only to rely upon it as the (positive) revelation of God's truths. The believer's task is not only to recognize the meaning of the words in Scripture but also to understand them according to the teachings of the Magisterium of the Church, for which one needs faith. Only within circumscribed faith can one receive Christian revelation.

Any sort of communication involves three components: messenger, message, and receiver. In the same way revelation includes God as messenger, his will as a message, and the faithful as a receiver of the message. It is akin to personal gift. If a gift is not received by someone it is not called a gift in its complete sense. In the same way, there must be an object as "subject" to receive what is

\footnotetext{
${ }^{37}$ Ibid., 64.

${ }^{38}$ Ibid., 67. Cf. IV. Lateran Council, DH 806.
} 
revealed by God. This "subject" is part of revelation; otherwise revelation does not occur, because "no veil has been removed." 39 Ratzinger stresses the necessity of tradition to understand Scripture as truths are passed on through tradition. In this manner one receives revelation. Hence, the Church, led by the Holy Spirit continues to reveal the hidden meaning of scriptures; and every believer in accordance with tradition - receives it and assents to it in faith, thereby growing beyond compare and human expectation.

\subsection{Different Layers of Understanding the Scripture}

The understanding of Scripture as revelation is not clear in Bonaventure's thought. Ratzinger noticed that Bonaventure's answer to the question of what constituted the spiritual understanding of Scripture was "wavering between two poles; one which is of academic and scientific and the other which is more prophetic." ${ }^{40}$ Bonaventure does not take a stand, but oscillates between the academic and prophetic approaches. The soul's movement towards God in prayerful speculation will lead one to receive revelation. In the Hexaëmeron, Ratzinger understood revelation as identification with "speculative-scientific exegesis of scripture." ${ }^{41}$ It is neither completely scientific nor completely speculative. Bonaventure preferred to give equal importance to both the scientific and speculative understanding of Scripture.

Bonaventure affirms that genuine speculation is connected with grace. Ultimately it is God who reveals Himself even in speculation. Bonaventure hoped to see the full explication of the content of revelation in the Franciscan and Dominican orders. He was convinced that revelation could be received in a more comprehensive way through their life and ministry of preaching and theologizing, thus bringing the spiritual understanding of Scripture into greater focus. He asserted that Francis anticipated the understanding of the Word of the Lord in a manner that was simpler than the understanding of Augustine and Dionysius. ${ }^{42}$ Citing Mt 11:25 "I praise you Father, Lord of heaven and of earth, that you have hidden these things from the wise and the clever, but have revealed them to the humble," Bonaventure, as a member of the Franciscan Order, perceived that his founder understood the mysteries of the word in a simple way, and humbly practiced this in his life. ${ }^{43}$ Bonaventure mentioned repeatedly that in the life of Francis, the Word of the Lord is fulfilled in a concrete way through humility. Bonaventure firmly believed in the indispensable relationship between humility and revelation. ${ }^{44}$

\footnotetext{
${ }^{39}$ J. Ratzinger, Milestones: Memoirs, 108.

${ }^{40}$ J. Ratzinger, The Theology of History in St. Bonaventure, 69.

${ }^{41}$ Ibid.

${ }^{42}$ Ibid., 71.

${ }^{43}$ Ibid.

${ }^{44}$ Ibid.
} 


\subsection{The Mediation of Revelation}

According to Bonaventure, revelation engages the entire cosmos along with the faith and humility of the individual. ${ }^{45}$ The celestial order: seraphim, archangels, angels and creation have their mediatory roles to play in the process of revelation. Jointly they play a "factual mediatorial function." 46 Bonaventure agreed with the notion of Hierarchy developed by Dionysius the Pseudo-Areopagite (ca. $500)^{47}$ as he seems to adopt the notion of celestial hierarchy from him. Moreover, the notion of Dionysius' celestial hierarchy incorporates the significant role of celestial beings in comprehending God's mysteries. Dionysius writes:

It is most fitting to the mysterious passages of scripture that the sacred and hidden truth about the celestial intelligences be concealed through the inexpressible and the sacred and be inaccessible to the hoi polloi. Not everyone is sacred, and, as scripture says, knowledge is not for everyone. ${ }^{48}$

For Dionysius, the intelligent and formless beings have more access to God and his words than human beings do. He believed that celestial beings had immediate access to God's revelation. Dionysius' theory of hierarchy made a significant impact on the concept of revelation in Bonaventure's thought. Bonaventure adopted his notion of hierarchy to explain the mediation of celestial being in revelation. ${ }^{49}$ The creature's knowledge of God relies upon the place that each being has in the hierarchy. Archangels have more knowledge of God than angels and the angels, in turn, have greater knowledge of God than human beings.

Bonaventure believed in the mediatory involvement of angels in revelation. ${ }^{50}$ Although Ratzinger accepts that angels have some involvement in the mediation of revelation, he disagrees with Bonaventure regarding the extent to which they are involved: he proposes that celestial beings have a role occasionaliter, because he wants to emphasize revelation as the sovereign action of God:

The only source of revelation is the divine ray of light. The light which illumines us immediately is the divine light. In the process of revelation, the angels act only occasionaliter like a man who opens the window and lets in the light though he himself is neither the source not the cause of the light. In this way revelation remains,

${ }^{45}$ Ibid., 72.

${ }^{46}$ Ibid.

${ }^{47}$ Pseudo-Dionysius, Pseudo-Dionysius: the complete Work, trans. L. Colm, New York 1987, p. 149. Bonaventure adopts the notion that the angels are involved in a mediatorial way in all revelations, but they are never the cause of revelation. The only source of revelation is the divine ray of light. The light, which illumines us immediately, is the divine light. In the process of revelation, the angels act only occasionaliter, like a man who opens the window and lets in the light though he himself is neither the source nor the cause of the light.

${ }^{48}$ Ibid., 149.

${ }^{49}$ J. Ratzinger, The Theology of History in St. Bonaventure, 89.

${ }^{50}$ Ibid., 74. 
on the one hand, entirely the work of God; on the other hand, it is withdrawn from all individualistic isolation and is placed in the context of the divine activity which embraces the world. In this context, every creature, as a part of the 'hierarchy,' is engaged in a holy work which takes its origin from God and leads back to God by way of fellow creatures. ${ }^{51}$

Angels are not the cause or source of revelation. It is entirely the work of God the creator. Creatures, because they receive life from God participate in a subordinate way in the process of revelation. René Latourelle, S.J., in his magisterial book, Theology of Revelation, highlights the teachings of the Church as formulated at the First Vatican Council. That council distinguished two types of divine manifestation: first, the natural manifestation of God through creatures; second, the manifestation of God through human reason. Bonaventure's notion of the involvement of all creation in revelation is in line with the teaching of Vatican I, as Latourelle writes:

Our Mother Church the Holy Church believes and teaches that God, beginning and end of all things, can be known with certainty in the natural light of human reason by means of creatures; in fact, what cannot be seen of Him can, since the creation of the world, be contemplated through his works... through the objective medium of creation and human reason is a certain revelation or manifestation of God, but a natural way. ${ }^{52}$

From this we may deduce that the mediatory role of the created order in natural revelation is positive. Nevertheless, Ratzinger gives more importance to God in revealing himself in a free act. In the process of revelation, human beings have prima facie a passive role in revelation, i.e. as a subject that receives rather than functioning in mediatory roles - but need appropriate it, i.e. live accordingly and testify to it, thereby becoming "subjects" of revelation.

\subsection{Scripture and Revelation - bound to Historical Development}

Ratzinger attempted to present the historical character of Scripture and revelation in Bonaventure's thought. He noticed an unfailing reliance on progress in the understanding of scriptures. The common denominator for Scripture and revelation is continuity and progress..$^{53}$ The following paragraphs illustrate progress and continuity in understanding Scripture through history.

The concept of history was viewed in the Middle Ages as "a flow of individual events; that which is common or general." ${ }^{54}$ The theologians of the Middle Ages tried to find the common element in all the individual events. Hence, there was no systematic science of history. Ratzinger cited Augustine's quote: "any-

\footnotetext{
${ }^{51}$ Ibid., 75.

${ }^{52}$ R. Latourelle, Theology of Revelation, Staten Island [USA, New York] 1966, p. 332.

${ }^{53}$ J. Ratzinger, The Theology of History in St. Bonaventure, 75.

${ }^{54}$ Ibid.
} 
thing historical should be believed but it cannot be understood." ${ }^{55}$ The African Church Father's statement suggests there is no secular grasp over the past. However, in this age of advancement in scientific research, one may not agree with Augustine. The modern age investigates every element of the past. It seeks scientific proofs of the past. Ratzinger argued that in Christianity the "unhistorical mode of thought" ${ }^{56}$ is less applicable.

Everything in the Old Testament is historical. Even more, Israel's history was written in the light of faith in Yahweh. Christianity is also a historically evolved religion. The notion of historical progress is presented in Hexaëmeron because of the flow of the individual events and their often hidden relation to one another. ${ }^{57}$ Thus, Ratzinger noticed the influence of scholastics in the development of Scripture and revelation.

Bonaventure emphasized the spiritual interpretation of scriptures. Scripture is merely a lifeless book until it is understood spiritually. It is not possible for an individual to understand Scripture spiritually without God's revelation and without looking back at the writings of saints. God inspires some individuals for this task; chief among them for Bonaventure were saints and church fathers like Augustine and Jerome to understand Scripture by reading their writings alongside Scripture. Thus, for Ratzinger, revelation is "a unique, delimited, and objectified reality which has been given its written fixation in the exegetical works of the Fathers." 58

Bonaventure preferred Hugh of St. Victor's (died 1142) concept of Sacred Scripture. For Hugh "Scripture and the Fathers flow together into one great Scriptura Sacra." ${ }^{59}$ Hugh places Scripture and the writings of the Fathers (traditio) on the same ground, as they both point to revelation. One observes the intimate connection between the Fathers of the Church with the scriptures. In Ratzinger's words, "they stand on an equal footing with any part of the Sacred Book, which as yet is not understood to be a unified book." ${ }^{60}$ The Fathers of the Church promulgated tradition through which revelation is understood. Both Scripture and patristic texts point to Christ. Ratzinger developed this thought further as peritus during the Second Vatican Council.

In Bonaventure's work, as is typical of the writings of other Scholastic thinkers, there is no unified understanding of the concept of revelation. Ratzinger notes the differences between our understanding of the concept of revelation, and the theories of thirteenth century theologians. Thirteenth century theologians referred to Scripture as revelation. ${ }^{61}$ Medieval theologians saw the problem of the canon

${ }^{55}$ Ibid., 76.

${ }^{56}$ Ibid.

${ }^{57}$ Ibid.

${ }^{58}$ Ibid., 78.

${ }^{59}$ Ibid.

${ }^{60}$ Ibid., 79.

${ }^{61}$ J. Ratzinger, Milestones: Memoirs, 109. 
when the scriptures and the writings of the Fathers were so closely connected as to be regarded on almost equal grounds. Though they revered the Fathers of the Church, they did not add their writings to the scriptures. Later this thought would give birth to the concept of tradition. In understanding the concept of tradition, the Fathers are considered "the bearers of a new spiritual 'revelation' without which Scriptures simply would not be effective as revelation." 62

New insights into scriptural exegesis were occasioned by the life of St. Francis. His impact on the medieval Church was profound. Because Francis sought to practice the teachings of Jesus in a simple and literal way, his radical example even affected the valence of the patristic exegetical tradition. His rule of life was the Sermon on the Mount, and it was evident to all that his sanctity was the result of a deep understanding, and practice of the Gospel. The literal meaning of Scripture, and the new form of life, paved the way for a more deliberate appreciation of the concept of tradition. Thus, the event of Francis gave rise to a controversy concerning the proper understanding of Scripture and tradition. ${ }^{63}$ Until the appearance of Francis on the stage of history, the writings of the Fathers were considered to be of utmost significance and to be part of a tradition to some degree. With the event of Francis, a new understanding of tradition came into existence. Tradition consisted not only of the writings of the Fathers, but also included other elements, such as liturgy, and sacraments. ${ }^{64}$

Ratzinger draws significant points in relation to the Bible and history: Scripture developed in an historical way. Scripture is not merely the record of past events, but also a "prediction of the future." Scripture's fullest meaning is not yet totally accessible because it encompasses the past, present, and future - in true Augustinian fashion. The understanding of the truths contained in Scripture continues to progress in every age and coincides with the dynamism of the process of revelation. Knowledge of the history of salvation is essential to the understanding of Scripture. ${ }^{65}$ However, Ratzinger prioritizes revelation over Scripture stating that: "Revelation precedes Scripture and becomes deposited in Scripture but is not simply identical with it... Revelation is something greater than what is merely written down. And this again means that there can be no such thing as pure sola scriptura." ${ }^{16}$ Ratzinger argues in the conciliar documents of Vatican II with this decisive statement.

\subsection{Creation and Revelation}

After discussing its manners of mediation, one can notice how both creation and the scriptures become vehicles for revelation. Bonaventure understood crea-

\footnotetext{
${ }^{62}$ J. Ratzinger, The Theology of History in St. Bonaventure, 80.

${ }^{63}$ Ibid., 82.6

${ }^{64}$ Ibid., $79-80$.

${ }^{65}$ Ibid., 83-84.

${ }^{66}$ J. Ratzinger, Milestones: Memoirs, p. 109.
} 
tion in the light of sapientia omniformis. For him, Scripture and creation are similar in many ways:

There is a striking parallel between the revelation of Scripture and that of creation. In both cases, the revelation is hidden behind the letters that veil it; in both cases, the unveiling of the revelation is the task of the Spirit who transcends the level of the literal in a living, existential movement which penetrates into the realm of the intellectual-spiritual. In both cases, there is also the danger of becoming imprisoned by the letters. ${ }^{67}$

The similarities between creation and the revelation in Scripture are quite striking. One of the significant elements common to revelation and creation is incomprehensibility. Neither revelation nor creation is fully comprehended by the human mind. The more one tries to understand them the more elusively complex revelation and creation appear.

Ratzinger alludes to the Itinerarium mentis in Deum, written by Bonaventure. There, revelation and creation are intimately connected. We come to know the greatness of the Lord through the created realities. Ratzinger quotes Bonaventure: "He, who does not allow himself to be illumined by the glory of created things, is blind; he who does not awaken to their call is deaf; he who does not praise God for all his works is mute. ${ }^{" 68}$ Created things on this earth reveal their Creator. Creation illumines one to understand God's deeds and Scripture unveils the mysteries of God.

Bonaventure strongly affirmed the hope of a final revelation; i.e., the ultimate explication of the mysteries of God, which would occur through a grand, eschatological event. He pointed to the progressive movement of revelation starting with the biblical patriarchs and continuing until the final days. This is a historical development in understanding revelation: "The historical ascent of the Church from the Patriarchs at the beginning to the People of God of the final days is simultaneously a growth of the revelation of God." ${ }^{69}$ Revelation is dynamic, living, and progressive in nature. In the final age, revelation becomes clearer to the faithful. Ratzinger states:

The mysticism... granted to the Apostles as to the 'perfect' depicts the stage of revelation of the final Church which is to be a Church of the perfect... The final age will involve neither the abolition of the revelation of Christ nor a transcendence of the New Testament. Rather, it involves the entrance into that form of knowledge which the Apostles had; and thus it will be the true fulfillment of the New Testament revelation which has been understood only imperfectly up till now. ${ }^{70}$

\footnotetext{
${ }^{67}$ J. Ratzinger, The Theology of History in St. Bonaventure, p. 85.

${ }^{68}$ Ibid., 86.

${ }^{69}$ Ibid., 92.

${ }^{70}$ Ibid., 92-93.
} 
The travails in understanding revelation continue until the second coming of Christ, when full knowledge of God will be imparted. Only in the final age can one understand revelation fully.

\subsection{Summary}

In summary, for Bonaventure, the spiritual interpretation of Scripture is revelation. He believed that only with divine (including sacramental) assistance could one interpret Scripture in a spiritual sense. The understanding of Scripture is always tied to a progressive movement which continues until the second coming of Jesus Christ. Progress in understanding revelation involves the whole cosmos, including angels and created things on earth. Therefore, it is reasonable to conclude that the notion of revelation has been developed in the history of the Church inspired by the Holy Spirit.

Bonaventure treated individual revelations in his Hexaëmeron. However, he failed to treat the public revelation of Christ, the Logos, which is behind all the individual revelations. In this ductus Ratzinger prioritizes Christ in understanding revelation. In this way, Ratzinger goes beyond Bonaventure's understanding of revelation. The extensive, critical study of Bonaventure's Hexaëmeron helped Ratzinger contribute crucially to the conciliar discussions. ${ }^{71}$

\section{Ratzinger and the Second Vatican Council}

\subsection{Ratzinger's Collaboration with Cardinal Frings}

Attending the Council, Cardinal Josef Frings (1887-1978) received schema$t a$ that were presented to the Council Fathers. ${ }^{72} \mathrm{He}$ forwarded these texts to Ratzinger for suggestions and critical review. Regarding the draft on divine revelation Ratzinger found something serious to reject. He believed that the Council Fathers gave more importance to Scholastic theology than to the Bible and the Church Fathers. He states: "They reflected more the thought of scholars than that of shepherds," ${ }^{\prime 3}$ but admits that the Council Fathers laid a strong foundation for the Council.

Cardinal Frings took Ratzinger with him to Rome along with two other theological advisors: Hubert Jedin (1900-1980) and Joseph Teusch (1902-1976).

${ }^{71}$ J. Ratzinger, Milestones: Memories, 109.

${ }^{72}$ Ratzinger speaks extensively of his experience in his book: Milestones: Memoirs 1927-1977, trans. E. Leiva-Merikakis, San Francisco 1997, 120-131. Also see, J. Ratzinger, Theological Highlights of Vatican II, trans. by The Missionary Society of St. Paul the Apostle in the State of New York, New York 1966.

${ }^{73}$ J. Ratzinger, Milestones: Memoirs, 120-121. 
Ratzinger's thoughts were readily accepted by Cardinal Frings. Many paid attention to the speech of Cardinal Frings, for he memorized his speeches - composed by the young peritus Ratzinger - and delivered them in clear Latin. ${ }^{74}$ By the end of the first session, Frings worked to have Ratzinger recognized as a permanent peritus. Ratzinger was highly esteemed and must be counted among the ten most important periti. He recalled how this opportunity facilitated his acquaintance with many renowned theologians at the Council, like Henri de Lubac, Jean Daniélou, and Gerard Philips. Ratzinger considered the days spent at the Council as grace-filled moments in his life because he had a chance to speak personally to many theologians from every continent. ${ }^{75}$ The intellectual collaboration between Cardinal Frings and Ratzinger before and during the Council was significant for the final shape texts would take. ${ }^{76}$

\subsection{The turbulent Debate on Revelation}

The Second Vatican Council's general congregation met on November 14, 1962 in St. Peter's Basilica. The first schema was De fontibus revelationis. ${ }^{77}$ There was an immediate objection to this draft from many of the Council Fathers. Sixty two percent of the bishops deemed the preparatory schema unsuitable to develop a constitution on revelation. They felt it reflected too much a Neo-Scholastic approach and dealt in a too defensive way with past controversies. ${ }^{78}$

The schema displayed an imbalance between tradition and Scripture. It reflected a naïve, historical view of the gospels and how tradition works in history. Frings expressed strong opposition to the schema and presented his views as prepared by Ratzinger in September, 1962. The underlying issue was a tension between different schools of theology which was misinterpreted sometimes as a struggle between a modernist and antimodernist stance. The preparatory schema, the work of the Vatican curia, was perceived as being antimodernist:

Should one continue the antimodernist attitude, the politics of closure, of condemnation, of defensiveness, until one ends in complete fearful refusal, or shall the church, once the necessary distinctions are made, turn to a new page, and step into a new, positive encounter with her sources, with her brothers, with the world of today $?^{79}$

${ }^{74}$ E. de Gaál, The Theologian Joseph Ratzinger at Vatican II, "Lateranum” LXXVIII/3 (2012), 515-548, at 517 .

${ }^{75}$ J. Ratzinger, Milestones: Memoirs, 121.

${ }^{76}$ E. de Gaál, The Theologian Joseph Ratzinger at Vatican II, 518.

${ }^{77}$ Ibid., 524.

${ }^{78}$ Ibid.

${ }^{79}$ L. Boeve, Revelation, Scripture, and Tradition: Lessons from Vatican II's Constitution Dei verbum for Contemporary Theology, "International Journal of Systematic Theology" 13 (October, 2011), 419. 
For Ratzinger, Vatican II was convoked i. a. to deepen the Catholic understanding of revelation as already expressed by the councils of Trent and Vatican I, and to propose its nature as more dynamic than heretofore appreciated. For him, revelation cannot be subjected to mean only, or minimized to human or written words. Christ, the Logos, is the complete revelation. Ratzinger preferred to highlight this Christocentric nature of revelation. Hence, he called for a dynamic understanding of revelation. Ratzinger's study of Bonaventure's Hexaëmeron clarified many things in this debate. Scripture in relation to revelation points to Christ, the fullness of revelation. The first schema presented by Rome overemphasized the process of the transmission of revelation, and deemphasized revelation itself, who is Christ the Logos. Ratzinger proposed that Scripture and tradition should be identified as the fontes cognoscendi, as God cannot be reduced to human words. ${ }^{80}$

Cardinal Frings presented this revised schema prepared by Ratzinger in the presence of many bishops and theologians. After further revision, the revised schema was accepted as the final, official view. ${ }^{81}$

Ratzinger recalled in his book Milestones that Josef Rupert Geiselmann's (1890-1970) unbalanced position helped him in refining the schema. Ratzinger pointed out that according to Geiselmann, the Council of Trent stated that revelation was contained "partially in Scripture and partially in Tradition." Later the authoritative statement took out "partim-partim," and stated revelation is contained in "scripture and tradition." Both Scripture and tradition speak of revelation. Based on the above analysis, Geiselmann came to conclude that:

Trent had wanted to teach that there can be no distribution of the contents of faith into Scripture, on the one hand, and Tradition, on the other, but rather that both Scripture and Tradition, each on its own, contain the whole of revelation, hence that each is complete in itself. ${ }^{82}$

Ratzinger pointed out the error in the theory of Scripture by Geiselmann, who understood Scripture as a "self-sufficient" source for revelation.$^{83}$ Ratzinger posed the fundamental question: how can revelation in its comprehensive sense be contained in human words? $?^{84}$

As the debate continued to understand the relationship between Scripture and revelation, it discussed the "material completeness" of the Bible in matters of faith. Ratzinger wrote:

${ }^{80}$ E. de Gaál, The Theologian Joseph Ratzinger at Vatican II: His Theological Vision and Role, 525 .

${ }^{81}$ J. Ratzinger, Milestones: Memoirs, 128-129.

${ }^{82}$ Ibid., 125.

${ }^{83}$ E. de Gaál, The Theologian Joseph Ratzinger at Vatican II: His Theological Vision and Role, 526.

${ }^{84}$ J. Ratzinger, Milestones: Memoirs, 126. 
This catchword (material completeness), which was immediately on everybody's lips and was regarded as a great new realization. Just as quickly became detached from its point of departure in the interpretation of the Tridentine decree. It was now asserted that the inevitable consequence of this realization was that the Church could not teach anything that was not expressly contained in Scripture, since scripture was complete in matters of faith. ${ }^{85}$

Ergo, the issue of the "material content of the Scripture and Tradition remains an open problem." $\$ 6$ The Second Vatican Council's concern was to stress the organic unity of Scripture and tradition and to reiterate the teaching of the Council of Trent, which sought the unity of Scripture and tradition. ${ }^{87}$ Scripture is not so self-evident as to answer all the questions that arise from faith. For this reason, the Council saw the importance of tradition. Hence, Ratzinger believes that scholars who approach Scripture solely on the basis of the historical-critical method will have no common agreement on the findings of history. Faith has to play a significant role in the areas of uncertain historical hypotheses. However, the question of how revelation can be contained in human words and written words was a pressing concern in the mind of Ratzinger. ${ }^{88}$

He noted that the sources of revelation, according to post-Tridentine Scholasticism are Scripture and tradition which would be related to the Magisterium. More recently, the historical-critical method of scriptural interpretation influences Catholic theology. "By its very nature" Ratzinger writes, "this historical critical method has no patience with any restrictions imposed by an authoritative Magisterium; it can recognize no authority but that of the historical argument." ${ }^{\prime 99}$ Sometimes the historical-critical method goes beyond the scope established by the Magisterium. This method does not easily accept the oral tradition, which continues parallel to Scripture and in fact gave rise to it. Instead, it comes forward to present another, corrective "historical knowledge" besides the Bible; a theory which undervalues the concept of tradition. There is a constant battle between the findings of the historical-critical method of interpretation and tradition..$^{90}$

After learning of the opposition and different views on the second schema, Pope John XXIII perceived the need to review the text in light of ecumenism and other pastoral concerns. The schema on Divine Revelation was revised by a spe-

${ }^{85}$ J. Ratzinger, Milestones: Memoirs, 125.

${ }^{86}$ R. Latourelle, Theology of Revelation, Staten Island [USA, New York] 1966, 454.

${ }^{87}$ The Decree on the Reception of the Sacred Books and Tradition of Trent teaches that "this truth and rule are contained in the written books and unwritten traditions that have come down to us, having been received by the apostles by the dictation of the holy Spirit, and have been transmitted, as it were, from hand to hand" (DH 1501). It is very clear from the above statement that the Church held and believed in the unity of both Scripture and tradition.

${ }^{88}$ J. Ratzinger, Milestones: Memoirs, 124-125.

${ }^{89}$ Ibid., 124.

${ }^{90}$ Ibid. 
cial commission. Karl Rahner and Ratzinger worked together in this commission to prepare the revised schema of the Dogmatic Constitution on divine Revelation. Ratzinger admitted that the revised proposal was more Rahner's work than his own. This proposal again faced reaction from the Fathers of the Council. Ratzinger noted that though Rahner and he agreed in certain matters, their approach differed because of their respective theological backgrounds. ${ }^{91}$ Rahner's schema was not accepted outright. The Constitution on Divine Revelation was completed only after further, complex debates. The crux of Ratzinger's thoughts on revelation was as follows:

Revelation, which is to say, God's approach to man, is always greater than what can be contained in human words, greater even than the words of Scripture... Scripture is the essential witness of revelation, but revelation is something alive, something greater and more: proper to it is the fact that it arrives and is perceived - otherwise it could not have become revelation... Revelation has instruments; but it is not separable from the living God, and it always requires a living person to whom it is communicated. Its goal is always to gather and unite men, and this is why the Church is a necessary aspect of revelation ... the historical-critical method cannot be the last word concerning revelation; rather, the living organism of the faith of all ages is then an intrinsic part of revelation... Tradition is precisely that part of revelation that goes above and beyond Scripture and cannot be comprehended within a code of formulas. ${ }^{92}$

Ratzinger gives great importance to the concept of revelation as fulfilled in Christ, the Logos, over Scripture and tradition as revelation. Scripture and tradition mediate revelation. Though Scripture and tradition mediate and express revelation, they are written and passed on in human words. For this reason Ratzinger, gives greater importance to revelation than to Scripture and tradition. One should understand Ratzinger's point with utmost delicacy. He does not downplay Scripture or tradition, but he is focused more on revelation as fulfilled in Christ. Thus, Ratzinger's Christocentric method is operative in the preceding arguments.

In the second session, the special commission presented its revised version of the text after couple of amendments on March 7,1964. The same commission divided the first chapter into two: 1 . revelation itself, and 2 . handing on divine revelation. After serious scrutiny and examination by the commission from June 1 to 6 of 1964, the first chapter was accepted without much difficulty. However, the second chapter failed to balance tradition and Scripture. The Council Fathers

${ }^{91}$ Ratzinger explains how Rahner differed from his thought: "As we worked together, it became obvious to me that, despite our agreement in many desires and conclusions, Rahner and I lived on two different theological planets... his theology was totally conditioned by the tradition of Suarezian scholasticism... His was a speculative and philosophical theology in which Scripture and the Fathers in the end did not play an important role and in which the historical dimension was really of little significance. For my part, my whole intellectual formation had been shaped by Scripture and the Fathers and profoundly historical thinking." - ibid., 128f.

${ }^{92}$ Ibid., 127. 
noticed that the second chapter gave greater importance to tradition in terms of containing truth than to Scripture. They expected to grant equal importance to Scripture and tradition. Hence, the commission amended the second chapter according to the advice of the fathers. ${ }^{93}$

The revised schema was discussed during the third session of the council from September 30 to October 6, 1964. In this session, the commission maintained a delicate balance between Scripture and tradition, which was accepted by the members of the Council. Considering everything, the text was acceptable to the Council Fathers on account of its Christocentric approach to Scripture. After discussing the disputed questions particularly in chapters I and II, the commission submitted the most recent draft to the council fathers on the last day of the third session. Ratzinger was the main contributing peritus in the final formulation of the Dei Verbum in 1964 that added numbers 21-26, found in chapter IV of that text. ${ }^{94}$

In the beginning the title for this document, as it was previously suggested, was De fontibus revelationis, but after many discussions, Ratzinger suggested two titles for this document on revelation: either De revelatione or De Verbo Dei. At the end it was decided to name it Dei verbum, which is very close to his second proposal. ${ }^{95}$ This indicates Ratzinger's remarkable contribution to the Dogmatic Constitution on Divine Revelation. Bl. Pope Paul VI solemnly promulgated Dei Verbum on November 18, 1965.

\subsection{Revelation and Scripture}

The difference between the sacred books of other religions such as the Bhagavad Gita or the Quran and the Holy Bible is that the former works are considered "timeless dictations," but the Bible is "God's historical dialogue." 96 Scripture witnesses to the revelation, but it does not contain the whole of revelation. The wholeness of revelation is found in Christ, the Logos. One cannot limit revelation to Scripture. God, in his ineffable love for humanity continues to reveal Himself in different ways. Ratzinger noted, "The biblical word bears witness to the revelation but does not contain it in such a way that the revelation is completely absorbed in it and could now be put in your pocket like an object." ${ }^{\text {"97 }}$ Scripture points to the knowledge of revelation. It cannot contain the entire revelation of God. Scripture is one of the significant mediums of revelation. Revelation is eminently dynamic in nature.

\footnotetext{
${ }^{93}$ R. Latourelle, Theology of Revelation, 454.

${ }^{94}$ Ibid.

${ }^{95}$ E. de Gaál, The Theologian Joseph Ratzinger at Vatican II: His Theological Vision and Role, 526.

${ }^{96}$ Ibid., 528.

${ }^{97}$ J. Ratzinger, God's Word: Scripture - Tradition - Office, trans. H. Taylor, ed. P. Hünermann and Th. Söding, San Francisco 2008, 122f.
} 
The words in the Scripture contain a surplus of meaning that goes beyond a mere historical setting. Scripture is "more than a text pieced together from what the individual authors may have intended to say, each in his own historical setting." 98 This stems from the fact that Scripture witnesses to the word of God, to which tradition also bears witness to.

The understanding of revelation, tradition, and scripture is determined by the two-fold shape of the Old and New Testaments. Only in the light of the Christevent is the Old Testament understood in its integrity. The New Testament sets the "Christ-event":

The formula that "Jesus" is the "Christ" signifies quite simply that the Christmessage of the Old Testament has come to fulfillment in the historical Jesus; that you can understand who Jesus is on the basis of the Old Testament and see what the Old Testament means in light of the Christ-event. ${ }^{99}$

The Old Testament is read in light of the Christ-event and the New Testament should be read within the framework of the prophecies of the Old Testament, which foresaw the coming of the Messiah.

According to Ratzinger, the Christ-event is reflected in the letters of Paul. He contrasts the Old and New Covenants as gramma and pneuma - (word and Spirit). Paul reasserts the prophecy of Jeremiah 31:33f.: Scripture is no longer needed, because the law is written in the heart; no one needs teaching from the outside anymore, because God himself teaches men. The coming of Christ is seen as an answer to the hope of the Old Testament. Accordingly Ratzinger argues: 'In the New Testament conception, the Old Testament appears as 'Scripture' in the proper sense, which has attained its true significance through the Christ-event by being drawn into the living sphere of the reality of Christ." ${ }^{100}$ Christ is the gravitational center of both the Old and New Testaments.

Scripture is surpassed by revelation in two ways: from above, by the words and deeds of God expressed in Jesus Christ, and from below, by what revelation makes present itself in the faith of the Church beyond the borders of Scripture. One can read Scripture without receiving it into one's heart. However, such a person cannot be acquainted with the dynamics of revelation. ${ }^{101}$ Thus, without faith, Scripture means nothing to the person who reads it. Revelation, which is from above, reaches all in mysterious ways by words and deeds. Scripture touches only people who read and believe it. On the other hand, revelation also affects non-Christians. Revelation, which is present both in the Church and the world, goes beyond the borders of mere text to renew and transform both.

\footnotetext{
${ }^{98}$ Ibid., 123.

${ }^{99}$ Ibid., 54.

${ }^{100}$ Ibid., 55.

${ }^{101}$ L. Boeve, Revelation, Scripture, and Tradition, 422.
} 


\subsection{The Problématique of the Concept of Tradition}

Western Christendom split apart in its understanding of the concept of tradition during the Reformation period. The dispute between the Reformers and Catholics centered on the meaning and significance of "tradition." Catholics described tradition as the transmission of revelation at the side of Scripture. ${ }^{102}$ However, in the Middle Ages, tradition was viewed as customs, worship, fasting, rituals and unity in following Christ in the universal Church. This deficient understanding of tradition negatively colored the term because of the abuses committed in the name of tradition.

As a reformer, Luther saw these practices leading away from Scripture, and thus deceiving people. The reformer from Wittenberg, who appreciated the simplicity of the Gospel, found the manifold religious customs useless and harmful. He saw human regulations occupying a place above God's Word. Ratzinger states some of the significant points in this regard from the Confessio Augustana (1530):

Where did the bishops get the right and power to impose such requirements on Christendom to ensnare men's consciences? ... If, then, bishops have the power to burden the churches with countless requirements and thus ensnare consciences, why does the divine Scripture so frequently forbid the making and keeping of human regulation? ${ }^{103}$

The Reformers misunderstood the concept of tradition as an abuse of positive ecclesiastical rules and regulations. According to the Reformers, one does not merit anything by one's efforts in conforming to these. Only by faith does one receive grace; one does not merit it by the laws that were instituted by human beings.

When Luther discovered the concept of justification by faith alone, without taking tradition into account, he felt God's Word was freed from the clutches of Church authorities. Luther felt that human regulations were placed above God's Word, and the Church's giving importance to the law which was abolished by the New Testament. Here, tradition is understood as a merely human regulation in opposition to the Gospel. According to the Reformers, one obtains grace from God sola fide, not by one's merits, or by following the precepts of the Church. ${ }^{104}$

Ratzinger summarized the dispute between Protestants and Catholics as follows: The Catholic understanding of Church includes three important elements: fides (corresponding to the pure decree), communio (corresponding to the sacramenta), and auctoritas. ${ }^{105}$ The Church is the criterion of the Word and not the

\footnotetext{
102 J. Ratzinger, God's Word: Scripture-Tradition-Office, 41.

${ }^{103}$ Ibid., 43.

${ }^{104}$ Ibid.

${ }^{105}$ Ibid., 44.
} 
Word, the criterion of the Church. The Word cannot stand independently as a separate entity without the Church. These standards were the main differences between Protestants and Catholics.

The Council of Trent (1545-1563) held that the Word cannot be a separate entity, so to speak "floating above" the Church. The Word is passed on through the Church and remains as it is beyond the reach of human authority. But the Protestant question remains the same: "Does the Word of God remain in the control of the Magisterium?" Ratzinger argues that the Lord, who established the Church as his body, could also preserve His Word. He believes that the Church is at the service of the Word. ${ }^{106}$

In order to find the way back Geiselmann, who taught dogmatic theology at Tübingen, proposed a new thesis. Geiselmann attempted to interpret the Council of Trent in a novel way regarding the nature of the Church and the sufficiency of the scriptures. Trent taught that the gospel was contained in libris scriptis et sine scripto traditionibus. ${ }^{107}$ Ratzinger argued that Scripture does not contain the whole veritas evangelii; therefore, there was no place for the principle of sola scriptura, because part of the truth was also passed on by tradition.

Geiselmann misinterpreted the position of Trent and claimed that truth was contained "partim in libris scriptis partim in sine scripto traditionibus:" truth is contained partly in scripture and partly in tradition. ${ }^{108}$ This articulates two sources of truth, namely Scripture and tradition. The council of Trent renounced the words partim-partim and added et between Scripture and tradition. In the end, Trent proposed that "Scripture and tradition contain truth." Geiselmann concluded that the council fathers of Trent turned away from the division of truth into separate sources. According to Geiselmann, even the Catholic theologian may argue for the "material sufficiency of Scripture and can also, as a Catholic, hold the opinion that Holy Scripture transmits revelation to us sufficiently." ${ }^{109}$ But for Ratzinger, this statement dilutes the true meaning of revelation.

Ratzinger sees the historical problem within this thesis proposed by Geiselmann. Ratzinger questioned the meaning of the self-sufficiency of Scripture. He observed that this would not adhere to the Catholic dogma and was a self-illusion. For him, the dogmas of Mary's Immaculate Conception (1854) and the Assumption of Mary (1950) would be deceptive and could not be sustained if one were to subscribe to Geiselmann's conclusions. Ratzinger believes that this long-standing problem between Protestants and Catholics concerning Scripture

${ }^{106}$ Ibid., 45.

${ }^{107}$ N.P. Tanner, Decree of the Ecumenical Councils. Vol. 2, Trent to Vatican II, London 1990, 663.

${ }^{108}$ J. Ratzinger, God's Word: Scripture - Tradition - Office, 48.

${ }^{109}$ Ibid., 48. 
could be resolved when we embark on the question of a correlation between revelation and tradition. ${ }^{110}$

According to Ratzinger, revelation cannot be reduced to Scripture alone. Revelation is the divine act and speech communicated to human beings about God and His will. Ratzinger notes that one need reach beyond the positive sources of Scripture and tradition and into their inner source. He writes:

Revelation is the living Word of God, from which scripture and tradition both spring and without which neither can be grasped in the importance they have for faith. The question of scripture and tradition remains insoluble so long as it is not expanded to a question of revelation and tradition. ${ }^{111}$

Revelation, who is Christ the incarnate Logos, is the one spring from which both Scripture and tradition issue forth. This is the Christocentric shift that Ratzinger so eloquently advocates and argues from. One can notice that Ratzinger adopted the Christocentric approach from Bonaventure. In his theology of revelation, Ratzinger emphasized revelation rather than merely focusing on Scripture and tradition. One can sum up that Christ, who lives in eternity, is higher than the sum of Scripture and tradition.

\subsection{The irreducible nexus between Revelation and Tradition}

Ratzinger works out fundamental theses regarding the relation between revelation and tradition, and interprets the concept of tradition along with the documents of Trent. In his concluding remarks, he states:

We are faced with a concept according to which revelation does indeed have its 'once - for - all' character, insofar as it took place in historical facts, but also has its constant 'today,' insofar as what once happened remains forever living and effective in the faith of the Church, and Christian faith never refers merely to what is past; rather, it refers equally to what is present and what is to come. ${ }^{112}$

For Ratzinger, revelation is not an end-product but rather an ongoing process to understand the self-disclosure of God. Tradition, like Scripture, is recorded and both point to the revealer, who is Christ. Tradition is comprised of:

1. The inscription of revelation (= the gospel) not only in the Bible, but in hearts;

2. The speaking of the Holy Spirit throughout the whole age of the Church;

3. The conciliar activity of the Church;

4. The liturgical tradition and the whole of the tradition of the Church's life. ${ }^{113}$

\footnotetext{
${ }^{110}$ E. de Gaál, The Theology of Pope Benedict XVI, New York 2010, 102.

${ }^{111}$ J. Ratzinger, God's Word: Scripture - Tradition - Office, 50.

${ }^{112}$ Ibid., 86-87.

${ }^{113}$ Ibid., 87.
} 
Jesus promised his disciples that the Holy Spirit would guide them to the truth. "He comes, the Spirit of Truth, he will guide you to all truth. He will not speak on his own, but he will speak what he hears, and will declare to you the things that are coming" (Jn 16:12-13). The Church, the body of Christ led by the Holy Spirit, continues to understand the revelation who is Christ. Understanding revelation as guided by the Holy Spirit is the "tradition" of the Church. Tradition can be regarded as a "living reality that encompasses both the learning process and the learning outcome of the whole church," 114 fueled by its listening and worship. Hence, tradition is not merely a matter of the Magisterium, but, of the entire Church.

\subsection{Christ - the Fullness of Revelation}

The reality of Christ, who is revelation, has a dual presence both in faith and in the Church. Both proclaim and interpret Our Lord. As proclamation of the Gospel by its very nature is interpretation, tradition by its nature is an interpretation of Scripture:

a. It is the interpretation of the Old Testament on the basis of the Christ- event.

b. It is the interpretation of the Christ-event itself on the basis of pneuma, and that means at the same time on the basis of the present ecclesiastical situation... Christ is not dead, but living; not merely the Christ yesterday, but just as much the Christ of today and of tomorrow. It is precisely in his Church, however, that he is living and present.

c. There is an Old Testament theology of the Old Testament, which the historian ascertains within the Old Testament and which has of course already developed a number of overlapping layers even there, in which old texts are reread and reinterpreted in the light of new events.

d. There is a New Testament theology of the Old Testament, which does not coincide with the Old Testament's own inner theology of the Old Testament, though it is certainly linked to it in the unity of the analogia fidei.

e. There is a New Testament theology of the New Testament which corresponds to the Old Testament theology of the Old Testament: As it is the theology that the historian can derive from the New Testament.

f. There is an ecclesial theology of the New Testament which we call dogmatics. It relates to the New Testament theology of the New Testament in the same way as the New Testament theology of the Old Testament relates to the Old Testament theology of the Old Testament. ${ }^{115}$

The Old Testament should be read in the light of the New Testament. The essential nature of revelation is to reveal the Triune God and his will. Hence God

\footnotetext{
${ }^{114}$ L. Boeve, Revelation, Scripture, and Tradition: Lessons from Vatican II's Constitution Dei verbum for Contemporary Theology, 423.

${ }^{115}$ J. Ratzinger, God's Word: Scripture - Tradition - Office, 59-61.
} 
encounters humanity personally by taking human form. The object of revelation is the "union of man with God in a life of communion." 116

The reality of revelation is Christ himself: "He who has seen me has seen the Father" (Jn 14:9). Receiving revelation means entering into relationship with Christ, who is the full revelation of God. The presence of Christ is the presence of revelation. The presence of Christ, as attested to by the scriptures, can be understood in two ways: first as it appears, as identical with faith (Eph 3:17), in which an individual meets Christ personally in faith, and in him enters Christ's saving power; second, it is also understood in Pauline terms as the body of Christ, which is the community of believers - the Church, through which he calls us to share his mighty presence. ${ }^{117}$ Believing means entering into a relationship with Christ, to which Scripture bears witness.

Revelation is an act of God, and the Church, instituted by Jesus Christ as an agent, receives the mysteries of truths. Ratzinger puts it thus:

The reception of revelation, in which the Christ-reality becomes ours, is called in biblical language 'faith'... for the New Testament, faith is equivalent to the indwelling of Christ. If we firmly hold that for scripture the presence of revelation is equivalent to the presence of Christ, a further step follows. We find the presence of Christ designated in two further ways. It appears on the one hand, identical with the faith (Eph 3:17), in which the individual encounters Christ and in him enters the sphere of influence of his saving power. But it is also hidden under the Pauline term of 'Body of Christ' which implies that the community of the faithful, the Church, represents Christ's continued abiding in this world in order to gather men into, and make them share, his mighty presence. ${ }^{118}$

Ratzinger observes that in the reception of revelation, the reality of the Christ-event becomes our own through faith. If we accept him, we accept his revelation. As the faithful are parts of the mystical body of Christ, Christ lives among them continuously revealing God the Father through the continuous guidance of the Holy Spirit.

The Dogmatic Constitution on Divine Revelation: Dei verbum is one of the most important documents of Vatican II. It should be read in light of previous pronouncements and teachings of the Church. The Council of Trent tried to clarify the questions raised by the Protestant Reformation. In its fourth session in April, 1546, the Council defined its attitude vis-à-vis the apostolic tradition and the Holy Scriptures.

In Spiritu Sancto legitime congregata,... hoc sibi perpetuo ante oculos proponens, ut sublatis erroribus puritas ipsa Evangelii in Ecclesia conservetur, quod promissum ante

\footnotetext{
${ }_{116}$ R. Schutz, M. Thurian, Revelation: A Protestant View, New York 1968, 13.

117 J. Ratzinger, God's Word: Scripture - Tradition - Office, 57.

${ }^{118}$ K. Rahner, J. Ratzinger, Revelation and Tradition, New York 1966, 40f.
} 
per Prophetas in Scripturis sanctis Dominus noster Iesus Christus Dei Filius proprio ore primum promulgavit, deinde per suos Apostolos tamquam fontem omnis et salutaris veritatis et morum disciplinae omni creaturae praedicari iussit [cf. Mc 16:15]; perspiciensque, hanc veritatem et disciplinam contineri in libris scriptis et sine scripto traditionibus, quae ab ipsius Christi ore ab Apostolis acceptae, aut ab ipsis Apostolis Spiritu Sancto dictante quasi per manus traditae ad nos usque pervenerunt. ${ }^{119}$

On January 6, 1870, at the end of the third session, Vatican I promulgated the constitution Dei Filius, which directly dealt with revelation and faith. The second chapter of the constitution explains revelation. First, it repeats the statements of the Council of Trent:

Haec porro supernaturalis revelatio, secundum universalis Ecclesiae fidem a sancta Tridentina Synodo declaratam continetur in libris scriptis et sine scripto traditionibus, quae ipsius Christi ore ab Apostolis acceptae, aut ab ipsis Apostolis Spiritu Sancto dictante quasi per manus traditae, ad nos usque pervenerunt. ${ }^{120}$

Both the Council of Trent and the First Vatican Council were faithful to tradition, which is one of the tools used to transmit revelation. Modern research reveals that the Council of Trent did not intend to divide revelation into two distinct, partial and independent sources, Scripture and tradition, but tried to express the unity of both with their common source, the Gospel. ${ }^{121}$ Vatican II goes beyond these two councils to address carious teachings of the Church. It did not limit itself to a dialogue with all Christians, but expressed the authentic doctrine on divine revelation and how it is passed on to us, which gave depth and clarity to various questions. ${ }^{122}$

The three significant aims of the Constitution on Divine Revelation were to clarify the relationship between tradition and the supposed self-sufficiency of Scripture, to formulate the concept of inspiration and to respond to the pre-conciliar biblical movement. The three aims were addressed with delicacy at the Second Vatican Council. While keeping the teaching of Trent, the Second Vati-

119 The English translation for the Latin text from $43^{\text {rd }}$ edition of Denzinger is as follows: "As the source of all saving truth and norms of conduct, the Council clearly perceives that this truth and rule are contained in the written books and unwritten traditions that have come down to us, having been received by the apostles from the mouth of Christ himself or from the apostles by the dictation of the Holy Spirit, and have been transmitted, as it were, from hand to hand" (DH 1501).

120 The English translation for the Latin text from $43^{\text {rd }}$ edition of Denzinger is as follows: "This supernatural revelation, according to the universal belief of the Church, declared by the sacred Council of Trent, is contained in the written books and unwritten traditions that have come down to us, having been received by the apostles from the mouth of Christ himself or from the apostles themselves by the dictation of the Holy Spirit, and have been transmitted as it were from hand to hand" (DH 3006).

${ }^{121}$ G.H. Tavard, Dogmatic Constitution on Divine Revelation of Vatican Council II, Glen Rock [USA, New York] 1966, 10.

${ }^{122}$ R. Schutz, M. Thurian, Revelation: A Protestant View, 12. 
can Council turned toward Christ and developed a Christocentric understanding of revelation. The Council did not restrict itself to Trent and Vatican I, but engaged in a critical hermeneutic of the teachings of these councils in light of new theological and ecumenical developments. The Council intended to avoid language that was static and notional, and instead adopted a language of dynamisms. In Dei Verbum, revelation is considered as the "living Word." The Council stresses faithful listening to the Word and proclamation with assurance. The text points at the evangelical themes of "word," "life," and "communion." 123

\subsection{The fruitful Tension between Natural and Supernatural Revelation}

The Council notes two forms of revelation: natural and supernatural. Natural revelation is from the created things in the world. Because they are created by God, they reveal their creator. Paul writes: "God manifests Himself to men so that they can know Him" (Rom 1:19). The universe points to the creator; God is the fullness of being. ${ }^{124}$

Supernatural revelation is different from the natural one. The gratuitous action of God makes it different. Revelation in this form opens up for a communion, a sharing of goods between God and creation. Natural revelation speaks about the Numinous; but supernatural revelation is God himself. God does not enter into a direct, personal dialogue with human beings in natural revelation. This can be compared to a person who is present, but does not communicate. Only in supernatural revelation does a human being encounter God.

In supernatural revelation, God intervenes personally, at a given point in time and space. He enters into a dialogue of friendship with man, making known to him the mystery of His innermost life, and plans for salvation. God invites humankind to a personal communion of life. Through faith, man is directly called by God, and he freely responds to the personal call of God and enters into a covenant with Him. ${ }^{125}$

The first chapter of Dei Verbum concerns "Revelation itself." In the second article it states:

Placuit Deo in sua bonitate et sapientia Seipsum revelare et notum facere sacramentum voluntatis suae [cf. Eph 1:9], quo homines per Christum, Verbum carnem factum, in Spiritu Sancto accessum habent ad Patrem et divinae naturae consortes efficiuntur [cf. Eph 2:18; 2 Pt 1:4]. Hac itaque revelatione Deus invisibilis [cf. Col 1:15; 1 Tim 1:17] ex abundantia caritatis suae homines tamquam amicos alloquitur [cf. Ex 33:11; Io 15:14s] et cum eis conversatur [cf. Bar 3:38], ut eos ad societatem Secum invitet in eamque suscipiat. ${ }^{126}$

${ }^{123}$ R. Schutz, M. Thurian, Revelation: A Protestant View, 11.

${ }^{124}$ R. Latourelle, Theology of Revelation, 337.

${ }^{125}$ Ibid., 339.

${ }^{126}$ The English translation of the Latin text from $43^{\text {rd }}$ edition of Denzinger is as follows: "In his goodness and wisdom, God chose to reveal himself and to make known to us the hidden pro- 
This article explains that the purpose of revelation by Christ is to make known to humanity the will of God. God communicates his will to humanity, so that the whole human race may take part in his divine life. In His high priestly prayer in John's Gospel, Christ prays to the Father, saying,

I revealed your name to those whom you gave me out of the world. They belong to you, and you gave them to me, and they kept your word. I pray not only for them, but also for those who will believe in me through their word, so that they may all be one, as you, Father, are in me and I in you, that they also be in us, that the world may believe that you sent me (Jn. 17:6, 20).

The purpose of God's revelation to humanity is to share in His divinity. Revelation is not primarily a content, information (revelata), but is itself the salvific event of God's self-revelation as Charity in Jesus Christ and the Spirit. ${ }^{127}$ Revelation is the encounter in person between God and humanity within a concrete history, which is part of salvation history and culminates in the incarnation of the Logos in Jesus Christ. The apostles and their successors handed on the revelation of Christ within the Church. Through Scripture and tradition the Church constantly deepens its understanding of revelation until the second coming of Christ.

Jesus Christ is the fullness of revelation - thus Ratzinger states the primacy of Christ in revelation as the mediator and content of revelation. Through him one comes to full and complete knowledge of God - to the degree granted by Him. Dei verbum affirms that Jesus Christ is the mediator and fullness of revelation: "the plan of revelation is realized by deeds and words... By this revelation, then the deepest truth about God and the salvation of man shines out for our sake in Christ who is both mediator and the fullness of all revelation" (DV 2). To see Jesus is to see his Father (Jn 14:9). Jesus perfected revelation:

Through His words and deeds, His signs and wonders, but especially through His death and glorious resurrection from the dead and final sending of the Spirit of Truth... we now await no further new public revelation before the glorious manifestation of our Lord Jesus Christ (DV 4).

This explains the primacy of Christ in revelation. "In times past, God spoke in partial and various ways to our ancestors through the prophets; in these last days, he spoke to us through a son, whom he made heir of all things and through whom he created the universe" (Heb 1:1). The faithful came to know God as Trinity through Jesus Christ. He spoke to humankind personally. Jesus is the mediator between God and humanity and the fullness of revelation. Through the

posal of His Will by which through Christ, the Word made flesh, man might in the Holy Spirit have access to the Father and come to share in the Divine nature" (DV 2. DH 4202).

${ }^{127}$ L. Boeve, Revelation, Scripture, and Tradition: Lessons from Vatican II's Constitution Dei verbum for Contemporary Theology, 421. 
Church, one continues to understand revelation. The centrality and finality of Christ is made clear in a letter of Paul:

[Christ] is the image of the invisible god, the first born of all creation, for in Him were created all things in heaven and on earth... He is before all things, and in Him all things hold together. He is the head of the body, the church. He is the beginning, the firstborn from the dead, that in all things He himself might be preeminent (Col 1: 15-20).

This Christological hymn proclaims Christ as preeminent in all things. This preeminence manifests the nature and scope of revelation. Christ is the mediator between God and human beings who takes primacy over all prophets, kings, and judges of the Old Testament, who pointed to him as the revealer of the Father.

The second chapter of Dei Verbum addresses the "Transmission of Divine Revelation." Dei Verbum opens with a citation from 1 Jn 1:2- 3: "What we have seen and heard we announce to you, so that you may have fellowship with us and our common fellowship be with the Father and his Son Jesus Christ." The Church proclaims the historical revelation of God in Christ and calls everyone to salvation. The Church highlights the Christocentric approach to explain revelation. Christ's revelation and his teachings are handed down over centuries according to the commandment of the Lord before his ascension: "Go into the whole world and proclaim the gospel to every creature" (Mk 16:15). Scripture and tradition are linked to the original transmission of the Gospel by the apostles, who passed on to the faithful by their preaching and examples all that they had received from Christ: His words, His ways, His life and His works. ${ }^{128}$

The concept of revelation bears important results for an understanding of tradition. By her teaching and liturgy the whole Church witnesses to it. Hence, tradition cannot be reduced to the transmission of static, doctrinal contents or limited to decisions made by Church authorities. In this context, Ratzinger points out the importance of the believers who contemplate and ponder the Word. In his commentary on Dei verbum he states:

The dynamics of this new view on tradition stem from the acknowledgement of the tension between 'what is expressed' and 'what remains unexpressed' in revelation, the all-encompassing character of tradition (referring to the teaching, life and worship of the ecclesial community), and the recognition that tradition develops over time, not only through its proclamation by the magisterium, but also through contemplation and study by believers, who 'ponder these things in their hearts' (Lk 2:19,51) through the intimate understanding of spiritual things, which they experience. ${ }^{29}$

In Ratzinger's view, tradition is not reducible to the Magisterium, since both are guided by the Holy Spirit. At the same time, the spiritual contribution of the

\footnotetext{
${ }^{128}$ L. Boeve, Revelation, Scripture, and Tradition: Lessons from Vatican II's Constitution Dei verbum for Contemporary Theology, 422.

${ }^{129}$ Ibid., 423.
} 
laity cannot be belittled, and should be taken into account. Both the divine and the human elements are engaged in the process of the transmission of revelation.

The question of revelation, proclaimed in Christ, and its presence in history split Western Christendom in the age of the Reformation. Ratzinger observed that the problem at that time was that Luther intended to equate traditio with abusus. The Council Fathers of Trent, on the other hand, had to face both the question of tradition and Reformation. According to Ratzinger's analysis, Trent was faithful to tradition, affirming that Scripture cannot stand independently, apart from the Church. He states "Trent continued to maintain that the Word is not a reality standing independently above the Church, but that it is delivered by the Lord to the Church." ${ }^{30}$ The Catholic Church transmits divine revelation through both Scripture and tradition.

\subsection{Summary}

In conclusion, the collaboration with Cardinal Frings gave an opportunity for Ratzinger to take part in the Second Vatican Council as one of its preeminent council theologians. His active participation and his theological insights made him one of the important theologians of the Council. His significant contributions to the Dogmatic Constitution on Divine Revelation, along with those of Karl Rahner and other theologians, were recognized by the Council Fathers.

Ratzinger's study of Bonaventure's theology helped him considerably in understanding the concept of revelation in drafting Dei Verbum. ${ }^{131}$ His theology of revelation is Christocentric. In his understanding of the concept of revelation, Ratzinger emphasizes the importance of revelation over Scripture and tradition. It is made clear that Scripture and tradition mediate revelation. They do not contain the fullness of revelation. Revelation goes beyond Scripture and tradition as it exists outside of both. Revelation is not restricted to Scripture and tradition written in human words. Ratzinger makes a strong effort to adhere to the teachings of the previous councils and understands revelation anew with a Christocentric approach.

\section{The Primacy of Christ in Revelation}

\subsection{The Desire for Knowing God}

The desire for God is innate in the human heart as man shares in the image of God. This drives our relentless quest for the knowledge of God and our strong desire to commune with God. Augustine expresses this desire in his Confessions:

${ }^{130}$ K. Rahner, J. Ratzinger, Revelation and Tradition, 29-30.

${ }^{131}$ E. de Gaál, The Theologian Joseph Ratzinger at Vatican II: His Theological Vision and Role, 526. 
"You stir us so that praising you may bring us joy, because you have made us and drawn us to yourself, and our heart is unquiet until it rests in you." ${ }^{132}$ Human history has witnessed many who aspired to know God through ardent devotion, prayer, sacrifices, and rituals.

The Catechism of the Catholic Church offers two ways of approaching the knowledge of God from creation: first, the physical world and second, the human person. In the physical world, creation reveals the invisible nature of God from its order, becoming, contingency, and beauty. As Paul writes: "For what can be known about God is plain to them, because God has shown it to them. Ever since the creation of the world his invisible nature, namely, his eternal power and deity, has been clearly perceived in the things that have been made" (Rom 1:19-20). The human person, by opening his or her heart to truth and moral goodness, and with an infinite urge for the ultimate Truth, attains knowledge of God to some degree:

Man's faculties make him capable of coming to a knowledge of the existence of a personal God. But for man to be able to enter into real intimacy with him, God willed both to reveal himself to man and to give him the grace of being able to welcome this revelation in faith. The proofs of God's existence, however, can predispose one to faith and help one to see the faith is not opposed to reason. ${ }^{133}$

As the human person has an innate desire for the knowledge of God, so also God, who created human beings in his image, willed to reveal himself to humanity. God, with his grace, enabled human persons to open their hearts to divine self-revelation. By virtue of his faculties, a human person is capable of knowing God to some degree, however this knowledge is limited.

\subsection{The Church and the Knowledge of God}

The Church is another important source from which one attains knowledge of God. Human reason attains a certain knowledge of God as natural law is written in the human heart. However, a number of obstacles prevent the human person from attaining complete knowledge. This is mainly due to the consequences of original sin. Thus, human beings depend on God's revelation and respond in faith by opening their hearts. Hence, only through God's revelation can personal acquaintance with God be attained: "God communicates himself to man gradually. He prepares him to welcome by stages the supernatural revelation that is to culminate in the person and mission of the incarnate Word, Jesus Christ." ${ }^{134}$

\footnotetext{
${ }^{132}$ The Confessions: Saint Augustine, ed. J.E. Rotelle, with an introduction, translation, and notes by Maria Boulding, New York 2005, 14.

${ }^{133}$ Catechism of the Catholic Church, Washington, DC $2000^{2}, 35$.

${ }^{134}$ Catechism of the Catholic Church. 39-40: "We can name God only by taking creatures as our starting point, and in accordance with our limited human ways of knowing and thinking. All
} 
God communicates himself through various means by different people throughout the history of salvation. God's plan of revelation had different stages in the history of salvation. ${ }^{135}$ The Father, through Jesus Christ, His Son, completes supernatural revelation via incarnation and mission: "In times past, God spoke in partial and various ways to our ancestors through the prophets; in these last days, he spoke to us through a son, whom he made heir of all things and through whom he created the universe" (Heb 1:1-2).

God revealed himself in human history. He willed to reveal himself and gave human beings the privilege to know him and to be united with him. "It pleased God, in his goodness and wisdom to reveal himself and make known the mystery of his will. His will was that all men and women should have access to the Father, through the Word made flesh, in the Holy Spirit, and thus become sharers in the divine nature." 136 God's eternal plan was to make human beings sharers in his divine nature. Jesus Christ, the Son of the Father, made this possible by taking human flesh and dying on the cross to unite humankind to God.

Contemporary theology connects revelation with incarnation. Present-day theologians assert that through Jesus Christ, God is revealed fully. Theologians such as H. de Lubac, K. Rahner, and R. Guardini reiterate that God revealed himself completely through Christ. In his human form, the Son of God revealed the Father. His gestures, signs, attitude, entire conduct and words reveal to us the identity of God the Father. ${ }^{137}$ Gaudium et Spes stresses the incarnate Word, the second Adam revealed by the Father:

Only in the mystery of the incarnate Word does the mystery of man take on light. For Adam, the first man, was a figure of Him who was to come, namely Christ the Lord. Christ, the final Adam, by the revelation of the mystery of the Father and His love, fully reveals man to man himself and makes his supreme calling clear. ${ }^{138}$

Only in light of the incarnation can one understand the fullness of revelation in Jesus Christ. Jesus Christ fulfilled the will of the Father on this earth. In God's plan, only in Jesus Christ, did God want to fulfill his revelation. The Church, which was instituted by Christ, accepts and responds to the revelation in faith. In this way, the Church goes beyond human reason in knowing God and his plan of salvation.

creatures bear a certain resemblance to God, most especially man, created in the image and likeness of God. The manifold perfections of creatures - their truth, their goodness, their beauty - all reflect the infinite perfection of God."

${ }^{135}$ Catechism of the Catholic Church, 54-65. God made known to the first parents with created realities. The revelation was not broken with the original sin. He continuously made covenants with individuals and Israel. He made covenants with Noah, Abraham, Israel his people and in the fullness of time he sent His Son as mediator to reveal Himself completely.

${ }^{136}$ Ibid., 51.

${ }^{137}$ R. Latourelle, Theology of Revelation, 359.

${ }^{138}$ GS 22. 
Ratzinger's theology of revelation emphasizes Christ, the revelation of the Father. By encountering Christ in the scriptures, in the sacraments, and in worship one comes to knowledge of God. Ratzinger's theology invites one to seek a more profound understanding of the concept of revelation in Christ.

The writings of Benedict XVI reflect a synchronic approach of faith and reason. His theology includes the whole history of human questioning that is relevant even today. He attempts to answer these questions employing the answers given in the course of history and strives to interpret God's self-revelation in Jesus Christ. In all his writings, the focus is on Christ. This Christocentric approach invites the readers to encounter Christ. ${ }^{139}$

\subsection{The Concept of Revelation in Ratzinger's post-conciliar Writings}

In his book Introduction to Christianity, Ratzinger reflects on the Apostolic Creed and challenges contemporary atheism. He retrieves the treasures of the Christian faith. Discussing the doctrine of the Blessed Trinity, he justifies negative theology to understand the Triune God. He highlights the danger of reducing God to limited human understanding. He notes "Any doctrine of the Trinity, therefore, cannot aim at being a perfect comprehension of God." 140 The mystery of the Blessed Trinity is not comprehended fully by contingent beings. Human language, reasoning, and comprehension of the mysteries of God are limited.

In understanding the doctrine of God, Ratzinger echoes the theology of Augustine who also employed the concept of "relativity" to understand the Trinitarian God. The relationship among the persons of the Triune God is "not something extra, added to the person, as it is with us; it only exists at all as relatedness." 141 For Ratzinger, the concept of "Son" is the concept of relation. The Father is not called "father" unless he has begotten children. When Jesus is called "Son," he is "relative" to the Father. According to the evangelist John, "Son" is a being from another. Jesus Christ is a being "from" and "toward" the Father. As an ambassador strips off his identity and represents the one who sent him, so also Jesus as the mediator represents and reveals the Father. Everything Christ did during his ministry on earth manifests the actions of God. Thus, Jesus is the "true ambassador" who reveals the Father. ${ }^{142}$

The application of the concept of Logos to Christ imparts significant meaning in the Gospel of John. Ratzinger states: "Logos does not mean simply the idea of the eternal rationality of being, as it did essentially in Greek thought ... it

${ }^{139}$ D. Vincent Twomey, Pope Benedict XVI: The Conscience of Our Age: A Theological Portrait, San Francisco 2007, 39f.

${ }^{140}$ J. Ratzinger, Introduction to Christianity, trans. J.R. Foster, San Francisco 2004, 171.

${ }^{141}$ Ibid., 183.

${ }^{142}$ Ibid., 182-188. 
no longer denotes simply the permeation of all being by meaning; it characterizes this man: he who is here is "Word."' 143 The ancient Greeks understood the term "logos" as "meaning or ratio," 144 but John focuses on the meaning of Logos as "Word" (verbum). There is a relation between the one who pronounces the Word and the Word that is being pronounced by the speaker. Once again, this indicates relation between the Father and the Son, Christ the Logos. The filial relationship between the Father and the Son was evident whenever Jesus prayed during his salvific mission on earth. According to Ratzinger, the Logos is not understood in an abstract sense, but as made visible to the world in Jesus, who is the Word of the Father.

Ratzinger notices the difficulties in understanding the second part of the creed: "I believe in Jesus Christ, his only Son, Our Lord." He points to the difficulty in understanding Christ in the man Jesus. For Ratzinger, one who tries to examine Christology with the historical-critical method alone faces the danger of reducing theology to history. ${ }^{145}$ The historical-critical method can demonstrate positively very much, but it cannot reach the height of faith. Amidst various modern theologies, Ratzinger tries to bring together both the historical Jesus and the Christ of faith, thus giving legitimacy to the historical-critical method without absolutizing it. He strongly believes that Christ and Jesus cannot be separated. He writes:

I believe that it can even become a very useful pointer to something, namely, to the fact that the one (Jesus) cannot exist without the other (Christ), that, on the contrary, one is bound to be continually pushed from one to the other because in reality Jesus only subsists as the Christ and the Christ only subsists in the shape of Jesus. ${ }^{146}$

Thus, for Ratzinger, the historical Jesus cannot be separated from the Christ of faith and the Christ of faith cannot be separated from the historical Jesus. One subsists in the other. If one separates Jesus and Christ in understanding Christology, one falls back into the Arian heresy. Ratzinger points out that Christ (Messiah, the anointed), is a title of Jesus, and eventually it became part of the name of Jesus. In his view, it is not possible to distinguish the person from his office. The office is the person and vice versa the person is the office. There cannot be any separation between "I" and the works, and what "I" does. In an ordinary sense, one understands the person by his or her actions. Hence, one cannot separate the works of Jesus from his office as Christ. ${ }^{147}$ Thus, one understands that

${ }^{143}$ Ibid., 189.

${ }^{144}$ Ibid.

${ }^{145}$ Ibid., 193. The same problem of understanding Christ Jesus is discussed in his book $B e$ hold the Pierced One, trans. Graham Harrison, San Francisco 1986, 13.

${ }^{146}$ J. Ratzinger, Introduction to Christianity, 201.

${ }^{147}$ Ibid., 203. 
Jesus' office as the one anointed (Messiah) cannot be separated from him. The integrity of the person of Jesus vouches for the harmonious collaboration of the human and divine natures.

\subsection{The Primacy of Christ in Revelation according to the Gospels}

As discussed above, one cannot divide Christ and Jesus. Jesus, as the anointed one, reveals God as Trinity. The purpose of God sending His Son into the world to save humanity was fulfilled when His Word became visible. God uttered Himself in Jesus once and for all. Revelation came to an end as it fulfilled this goal. Ratzinger reiterates, "The fact that in Christ the goal of revelation and, thereby, the goal of humanity is attained, because in him divine existence and human existence touch and unite, means at the same time that the goal attained is not a rigid boundary but an open space." 148 Because Christ was truly human and truly divine, he was fully united with God and fully united to humanity. In this way, the fullness of revelation was made possible in Jesus Christ. There is nothing hidden in God that was not revealed in his Son Jesus Christ.

When God revealed himself, he appeared as charity and meek gentleness in the incarnation of Christ. However, for Ratzinger, one of the significant ways that God revealed himself in Jesus was through the Cross. The Cross revealed both God and man to humankind. ${ }^{149}$ Ratzinger, in his classic Introduction to Christianity, argues that Jesus' death on the cross is a revelation of God, citing Plato's (albeit interpolated) image of the crucified "just man." The position of a truly just man in this world is when a righteous man takes the place of an unrighteous one to make others righteous. Though this was said long before the birth of Jesus, it was fulfilled in Jesus, the "Just One." Jesus identified himself with the unrighteous and sinners. Jesus' death on the cross revealed both God and man. He identified and sympathized with man. Jesus revealed the abundant love of the Father to sinful humanity. Hence, the cross is truly the center of revelation. It revealed how sinful humankind is and how merciful God is. As dust is seen clearly in light, so human sinfulness is seen at the cross. Thus, Ratzinger claims that the cross revealed both God and man. ${ }^{150}$

The Son of God reveals the depth of His love for humanity on the cross. The cross becomes the center of revelation among many other ways: God is revealed also in the incarnation, in the miracles, in forgiving sinners, in the parables, and in living among the poor. Thus, it is not only on the cross that Jesus Christ revealed God, but throughout his earthly mission.

The filial relationship between Jesus and the Father through prayer is evident in the gospels. Jesus prays before all important events in his life: before

\footnotetext{
${ }^{148}$ J. Ratzinger, Introduction to Christianity, 263.

${ }^{149}$ Ibid., 292.

${ }^{150}$ Ibid., 293.
} 
calling the twelve, before the Transfiguration, in the Mount of Olives, and on the cross. Jesus calls God "My Father," but he invites his disciples to pray with him the "Our Father." Only Jesus can address God as "My Father" because of his Sonship and relation with the Father. Human beings are entitled to call God Father because he created us in his image. But no one can build a bridge between the Father and humanity except Jesus Christ. This bridge is made possible only through Jesus, the mediator, who fully reveals the Father. ${ }^{151}$

As a human being, Jesus had an intimate relationship with the Father despite being one with humanity. He lived his religious life like any other Jew of his time. Ratzinger alludes to the dialogue with Moses and Elijah on the mountain (Mk 9:4) in order to present Jesus' unique place in revelation. Ratzinger believes that Jesus went beyond the Old Testament prophets in his relationship with the Father. In doing so, Jesus displayed a profound knowledge of the Father. ${ }^{152}$ Because he was both human and divine, his knowledge and relationship with the Father superseded that of others.

In his book On the Way to Jesus Christ, nota bene under the subtitle The Face of Christ in Sacred Scriptures, Benedict presents the "face of Jesus" and Jesus' identity as revealer of the Father on the basis of the Gospel according to John: When Jesus foretells his passion and death to his disciples, Thomas asks: "Lord, we do not know where you are going; how can we know the way?" (Jn 14:5). Jesus answers him saying, "I am the way, and the truth, and the life; no one comes to the Father but by me" (Jn 15:6). This raises another question from Philip, who asks Jesus "Lord, show us the Father, and we shall be satisfied" (Jn 14:8). Jesus reveals his identity again saying "He who has seen me has seen the Father" (Jn 14:2-9). This dialogue with his disciples is the strongest evidence that Jesus Christ is the revelation of the Father. However, Jesus' answer surprises Philip: Whoever has seen Jesus has seen the Father. This reveals the intimate relationship between the Father and Son. It is echoed by Paul when he writes "For God who said, 'Let light shine out of darkness,' has shone in our hearts to bring to light the knowledge of the glory of God on the face of Jesus Christ" (2 Cor 4:6). The light of Jesus Christ shed on humankind brings it to the knowledge of God. ${ }^{153}$

Another explanation that Benedict presents to show the primacy of Christ in revelation is a comparison of Jesus with the prophets of the Old Testament. God reveals himself through the prophets in the Old Testament; for instance "The Lord used to speak to Moses face to face, as a man speaks to his friend" (Ex 33:11). Moses again requests of God "Show me your glory!" and the Lord says "You cannot see my face; for man shall not see and live" (Ex 33:18-23). In contrast to

\footnotetext{
${ }^{151}$ Ibid.

${ }^{152}$ J. Ratzinger, Behold the Pierced One, 29.

${ }^{153}$ J. Ratzinger, On the Way to Jesus Christ, trans. M.J. Miller, San Francisco 2005, 13-16.
} 
Moses who desires to see the face of God, Christ sees the face of God, and in his own face the glory of God is made visible. More than a prophet and a friend, Jesus is the "Son." Jesus said that his disciples were no longer called slaves but friends and all believers have access to the knowledge of God through Jesus Christ. The knowledge of God is made accessible by encountering Christ. Thus, most concretely Jesus Christ is the face of God, who reveals the glory of God. ${ }^{154}$

\subsection{The Primacy of Christ in Revelation in the Letters of Paul}

In Pauline Christology, Christ is the "image of the invisible God" (Col 1:15). Paul, in his Christological hymn, highlights the relationship of God and Christ: "He is the image of the invisible God, the first born of all creation... He is before all things, and in him all things hold together... He is the beginning, the firstborn from the dead, that in all things he himself is preeminent" (Col 1:15-19). For Benedict, the Letter to the Philippians emphasizes the way in which God is revealed in the self-abasement and exaltation of Christ and the Letter to the Colossians highlights the mystery of God revealed in Christ. ${ }^{155}$

Benedict XVI explored the legacy of Paul in his Wednesday audiences in the "Pauline Year." ${ }^{156}$ Benedict reflected on Jesus as the head (kephalé) of the Church in the theology of Paul: "He is the head of the body the Church" (Col 1:17). As the head, Jesus is the governor, the leader, and the guide who leads the Christian community. He also innervates and vivifies the members in the one body. ${ }^{157}$ Living the truth in love, the faithful should grow in every way into him who is the head, the Christ, from whom the whole body is joined and is held together by every supporting ligament... (Eph 4:15-16). Citing the above Pauline texts, Benedict XVI affirms:

$\mathrm{He}$ is the governor, the leader, the person in charge who guides the Christian community as its leader and Lord... he innervates and vivifies all the members of the body that he controls... he is not only one who commands but also one who is organically connected with us, from whom comes the power to act in an upright way. ${ }^{158}$

\footnotetext{
${ }^{154}$ J. Ratzinger, On the Way to Jesus Christ, 26. See also Jesus of Nazareth, vol. I, 265.

${ }^{155}$ F.J. Matera, God's Saving Grace: A Pauline Theology, Grand Rapids [USA, Michigan] 2012, 242.

${ }_{156}$ Pope Benedict XVI, St. Paul, San Francisco 2009, 7. The year from June 29, 2008 to the same feast on 2009 was dedicated to the great Apostle Paul. According to Pope Benedict, "The Apostle Paul, an outstanding and almost inimitable yet stimulating figure, stands before us as an example of total dedication to the Lord and to his Church as well as of great openness to humanity and its cultures."

${ }^{157}$ Pope Benedict XVI, St, Paul, 111-112.

${ }^{158}$ Ibid., 112.
} 
As the head of the Church, Jesus Christ leads and directs the Church. As the head is a significant part of the human body that directs the other organs to function, so Christ directs, guides, and nourishes. He is supreme over the Church and its tradition.

The Church is "subjected" to Christ; she must be both guided and vivified by him. It is Christ who appointed the apostles, some as prophets and others as evangelists, others as pastors and teachers (Eph 4:11). Thus Jesus Christ guides, empowers, and leads the Church in the right direction. When the Church passes on its teaching or proclaims dogma, Christ guides the Church. Benedict observes that the work of governance is not traced back to the Spirit, but to Christ (1 Cor 12). ${ }^{159}$ After the Ascension, everything that was carried out in the Church was attributed to the Spirit. But here, we notice that it has been attributed to Jesus Christ as the governor of the Church.

Christ is not only the head of the Church, but he is also superior to the heavenly beings. The cosmos is subject to him and converges in him as its head. Citing Ephesians 1:10: "to unite all things in him, things in Heaven and things on earth," Benedict XVI goes on to say: "Christ has no possible rival to fear since he is superior to every form of power that might presume to humble man." 160 Christ revealed God the Father so profoundly that his footprints are the very footprints of God. Christ himself is God's impression. Hence, he affirms the primacy of revelation in Christ. For him, centrality and finality is Christ over everything else. He is supreme over all things visible and invisible.

\subsection{Revelation in Benedict XVI's Trilogy Jesus of Nazareth}

Benedict XVI presents Jesus to the world in the three-volume work, titled Jesus of Nazareth. ${ }^{161}$ In the first volume, Benedict demonstrates the commonalities and differences between Moses and Jesus. "From his fullness have we all received, grace upon grace. For the law was given through Moses; grace and truth came through Jesus Christ, no one has ever seen God; it is the only Son, who is nearest to the Father's heart, who has made him known" (Jn 1:16-18). Citing this passage, Benedict claims that Jesus made God the Father known to humanity as revealer of the Father. The Law was given through Moses, but Jesus Christ brought grace upon grace to the world and has shown the love and mercy of God. ${ }^{162}$

${ }^{159}$ Ibid.

${ }^{160}$ Ibid., 113.

${ }^{161}$ These volumes of Jesus of Nazareth are his personal search "for the face of the Lord" states, Benedict (Vol. 1, xxiii). The first volume, From the Baptism in the Jordan to the Transfiguration deals with the public ministry of Jesus. The second volume, Holy Week: From the Entrance into Jerusalem to the Resurrection discusses the passion narratives of Jesus. The third volume, Infancy Narratives discusses the birth of Jesus Christ.

${ }^{162}$ J. Ratzinger, Pope Benedict XVI, Jesus of Nazareth: From the Baptism in the Jordan to the Transfiguration, trans. A.J. Walker, New York 2007, 236. 
God had already revealed his name to Moses and built a relationship with humankind. He communicated His will to Moses. Moses acted as the mediator between God and Israel in the Old Testament. In his high priestly prayer, Jesus emphasized that he revealed the name of the Father (cf. Jn 17:6, 26). Jesus brought to completion what began with Moses. Benedict observes that Jesus goes beyond any prophet in revealing God. ${ }^{163}$ The face of Jesus was revealed whenever he spoke and acted in the name of the Father. Jesus was never alone. There was reciprocity between the Father and the Son. Benedict reflects on this perfect unity of the Father and the Son in his first volume of Jesus of Nazareth, speaking about the face of Jesus:

Jesus' own 'I' is always opened into 'being with' the Father; he is never alone, but is forever receiving himself from and giving himself back to the Father: 'My teaching is not mine'; his 'I' is opened up into the Trinity. Those who come to know him 'see' the Father; they enter into this communion of his with the Father. ${ }^{164}$

Jesus' teaching is not his own, but from the Father. His words are the words of the Father and his works are the works of the Father. Jesus is the Word of the Father. Hence, Jesus revealed the Father in all the aspects of his life on earth. Benedict calls attention to the evangelist John, who does not present a genealogy at the beginning of his gospel, but presents Jesus as the Logos in his Prologue. Pope Benedict investigates the question of Jesus' provenance in the Gospel of John in his book Jesus of Nazareth: Infancy Narratives. He states: "Jesus' origin, his provenance, is the true 'beginning' - the primordial source form which all things come, the 'light' that makes the world into the cosmos. He comes from God. He is God." 165 The three volumes of Jesus of Nazareth show remarkable continuity and coherence in his theology from his earliest writings onward.

Also in these three volumes Benedict supports his argument: "the face of Jesus" as the revealer of God the Father. Thereby, he maintains a Christocentric approach to affirm that Christ goes beyond all prophets in revealing God. His Christocentric point d'appui is irreproachably consistent with Scripture and the tradition of the Church.

\subsection{Further Elucidations on God's personal Self-disclosure in Christ}

During his pontificate, Benedict penned a number of exhortations and encyclicals. Some of these writings demonstrate his Christocentric theology and the person of Jesus as the definitive revelation. Oftentimes in his encyclicals, Benedict invites the faithful to encounter Christ through Scripture and the sacraments.

${ }^{163}$ J. Ratzinger, Pope Benedict XVI, Jesus of Nazareth: From the Baptism..., 267.

164 Ibid., 283.

165 J. Ratzinger, Pope Benedict XVI, Jesus of Nazareth: The Infancy Narratives, trans. Ph.J. Whitmore, New York 2012, 11. 
The theme of encountering Christ pervades all his writings. A selection of these papal writings illuminates the concept of revelation and the Christocentric approach which he already unfolded profoundly at Vatican II.

\section{a) Deus Caritas Est}

Benedict wrote his first encyclical, Deus caritas est, on God's love for humanity. In a world where the name of God is sometimes associated with vengeance or even hatred, Benedict seeks to speak of the limitless love that God bestows on humanity. The first section of the encyclical focuses on God's love and the reality, or potential, of human love. Here, Benedict demonstrates God's love as the highest form of love, agape. In the second part, he discusses the commandment to love one another.

In the introduction, Benedict elucidates what it means to be a Christian in terms of encountering Christ the Son of God. He states: "Being Christian is not the result of an ethical choice or a lofty idea, but the encounter with an event, a person, which gives life a new horizon and a decisive direction." 166 A Christian should encounter Christ, who is the revealer of God's love in his words and actions. Unless one is rooted in Christ, he or she will not be able to present Christ as love to the world.

Jesus Christ is the incarnate love of God. Benedict reflects the New Testament, particularly focusing on figure of Christ, who gives himself to us. In Jesus Christ, God searches for his lost sheep. Benedict believes that divine activity took on a dramatic form when Jesus lived among the outcasts, the poor, and sinners. In Jesus Christ, God showed his love to humanity. God is revealed in Christ Jesus most explicitly on the cross in a most radical form - to raise us up to himself. Benedict goes on to say that in Christ we see the invisible God. He reiterates:

True, no one has ever seen God as he is. And yet God is not totally invisible to us; he does not remain completely inaccessible... He has become visible in as much as he 'has sent his only Son into the world, so that we might live through him' (1 Jn 4:9). God has made himself visible: in Jesus we are able to see the Father (cf. Jn 14:9). ${ }^{167}$

God made himself visible in Christ Jesus; the faithful see God in Jesus Christ. Through Jesus Christ the faithful experience the love of the Father. An encounter with Jesus is the encounter with God. In encountering Christ, one encounters God in His human nature.

${ }^{166}$ Benedict XVI, Encyclical Letter: Deus caritas est. art. 1. http://www.vatican.va/.../hf_ben_ xvi_enc_20051225_deus-caritas-est_en.html_[accessed: October 2, 2014].

${ }^{167}$ Ibid., art. $1 \overline{7}$. 


\section{b) Spe Salvi}

Benedict XVI, in his second encyclical Spe salvi, presents a masterful survey of the abandonment of Christian hope in favor of faith in progress and technology, which ultimately led to atheism and communism and more suffering for humanity. He contends that man's true hope is not found in ideologies but in God who has loved man to the end.

According to Benedict, only in encountering the person of Christ can one have hope amidst innumerable problems in the modern world. In order to hope in Jesus Christ in hopeless situations, Benedict draws the attention of the reader to the Letter to the Ephesians and explains that, "The Ephesians, before their encounter with Christ, were without hope because they were "without God in the world.' To come to know God - the true God - means to receive hope." ${ }^{68}$ Only in encountering Christ can one possess and receive hope. Only in knowing him, can one come to the knowledge of the redemption Christ brought to humankind. If one is cognizant of Jesus' redemptive work through his death on the cross, one acknowledges and accepts him as one's hope. This kind of hope not only enables one to endure the sufferings of this world, but also transforms oneself and allows one to become truly oneself. It is in and through Jesus that one hopes in God. Christ elevates man's hope in God. The Ephesians had no hope before encountering Christ, for they did not find God in the world. When they came to the knowledge of God through the gospel of Christ, they came to the knowledge of the true God whom Jesus revealed.

Benedict calls the attention of the faithful to the first writing of Paul to the Thessalonians: "You must not grieve as others do who have no hope" (1 Thess 4:13). Likewise Benedict exhorts the faithful to have hope in God, which should be a distinguishing mark of the Christian life. Man has a future, but he does not know the details of what awaits him in the future. Nevertheless, a person knows that God holds his future and he knows that it will not end with emptiness. ${ }^{169}$ Reflecting on the "image of God" in Christ, Benedict notes: "God has given himself an image: In Christ who was made man. In him who was crucified, the denial of false images of God is taken to an extreme. God now reveals his true face in the figure of the sufferer who shares man's God-forsaken condition by taking it upon himself." ${ }^{170}$ God's true face is found in the suffering Jesus who laid down

${ }^{168}$ Benedict XVI, Encyclical Letter: Spe salvi, art. 3. http://www.vatican.va/holy.../hf_benxvi_enc_20071130_spe-salvi_en.html [accessed October 2, 2014].

${ }^{169}$ Benedict XVI, Spe salvi, art. 2. "The Christian message was not only 'informative' but 'performative.' That means: the Gospel is not merely a communication of things that can be known - it is one that makes things happen and is life-changing. The dark door of time, of the future, has been thrown open. The one who has hope lives differently; the one who hopes has been granted the gift of a new life."

${ }^{170}$ Ibid., art. 43. 
his life for humanity. The innocent suffering of Christ on the cross offers the assurance of hope: God in his mysterious ways offers us justice which we can conceive of only in faith.

Benedict's encyclical Spe salvi exhorts the people of the modern world to find hope by encountering Christ on the cross. Here again one notices Benedict's Christ-centered theology and his continuity of thought.

\section{c) Caritas in Veritate}

Benedict XVI's third encyclical, entitled Caritas in Veritate, starts with a discussion of Christ, who witnessed to the truth: "Charity in truth, to which Jesus Christ bore witness by his earthly life and especially by his death and resurrection, is the principal driving force behind the authentic development of every person and of all humanity." ${ }^{171}$ The strength of the encyclical lies in its use of theology to direct Catholics and other Christians away from thinking in a secular way about the questions of politics and economics.

Benedict examines the social teachings of the Church already voiced by popes in the past, such as Rerum Novarum (1891) by Leo XIII, Populorum Progressio (1967), Humanae Vitae (1968), and the apostolic exhortation Evangelii Nuntiandi (1975), all three by Paul VI. With his Chalcedonian approach to interpreting the truth and charity, Benedict once again orients his logical arguments towards Christ the revealer of the Father and humanity itself. He states:

In promoting development, the Christian faith does not rely on privilege or positions of power, nor even on the merits of Christians but only on Christ, to whom every authentic vocation to integral human development must be directed. The Gospel is fundamental for development, because in the Gospel, Christ, 'in the very revelation of the mystery of the Father and of his love, fully reveals humanity to itself.' ${ }^{172}$

Benedict focuses on the integral development of the human person, not just the material development of society. Knowing more, having more, and doing more should be integrated with the truth. Human development should not be confined to one nation or culture. Development is not comprehensive if it excludes any group of people, any culture, or any nation. Human development should aim at the good of every person and of the whole person. ${ }^{173}$

Benedict invites the Church to give importance to value every individual equally. Human development does not rely on the power and position possessed in this world but relies on Jesus Christ. Benedict points out that God gives a "resounding yes" to the pleading of human beings who cry for help. He calls on us

${ }^{171}$ Benedict XVI, Encyclical Letter: Caritas in veritate. art.1. http://www.vatican.va/.../ hf_ben-xvi_enc_20090629_caritas-in-veritate_en.html_accessed: October 2, 2014].

${ }^{172}$ Ibid., art. 18.

${ }^{173}$ Ibid. 
to open our hearts and to pursue an integral development of humanity. The Christian vocation to this development achieves its perfection only in Christ. ${ }^{174}$

\section{d) Verbum Domini}

Verbum Domini is a response to the twelfth Ordinary General Assembly of the Synod of Bishops, which met in 2008. Its theme was The Word of God in the Life and the Mission of the Church. ${ }^{175}$ One of the significant goals of the assembly was to review the implementation of the directives on Scripture as found in the Second Vatican Council, especially its dogmatic constitution Dei Verbum. Another goal was to address the new challenges of the day.

In this post-synodal apostolic exhortation Verbum Domini, Benedict points out some fundamental approaches to rediscovering the Word of God in the life of the Church. ${ }^{176}$ The document has three parts entitled Verbum Dei, Verbum in Ecclesia, and Verbum in Mundo.

Initially, Benedict reflects on the journey of the universal Church from Dei Verbum to the Synod on the Word of God. For Benedict, the Word of God is the "heart of the Christian life." The Church is built and grows on the Word of God. Saints and faithful have found strength in the Word of God. Benedict invites the Christian communities to study, meditate, celebrate, and be strengthened by the Word of God. ${ }^{177}$ The Word of God leads and transforms the lives of the people. Benedict exhorts the universal Church to encounter Christ in Scripture. This Word is Jesus Christ. Benedict reiterates that Jesus Christ is "the fullness of revelation." He writes:

Jesus Christ is to be acknowledged as 'mediator and fullness of all revelation.' To each generation the Church unceasingly proclaims that Christ 'completed and perfected revelation. Everything to do with his presence and his self-manifestation was involved in achieving this: his words and works, signs and miracles, but above all his death and resurrection from the dead, and finally his sending of the Spirit of truth. ${ }^{178}$

In the above statement Benedict again affirms Jesus as the fullness of all revelation. Jesus Christ reveals God the Father to this world by his words and deeds and by his Paschal Mystery, which is the ultimate expression of God's love for humanity. When God spoke in history, the same Word was present. "God was never without Logos." 179 The heart of divine revelation is the Incarnation. God

${ }^{174}$ Benedict XVI, Encyclical Letter: Caritas in veritate, art. 18.

175 Benedict XVI, Post-Synodal Exhortation: Verbum Domini. http://www.vatican.va/.../ hf_be_xvi_exh_20100930_verbum-domini_en.html [accessed: October 2, 2014].

${ }^{176}$ Ibid., art. 1.

${ }^{177}$ Ibid., art. 3.

${ }^{178}$ Ibid.

${ }^{179}$ Ibid., art. 6. 
made known His mysteries to humankind when He took human form in Jesus Christ and this Word of God is handed on in the Church's living tradition.

Benedict notes that the fullness of revelation in Christ is witnessed by Scripture and living tradition. Jesus revealed the Father fully, and thus there will be no further public revelation. The same assertion is maintained in the Catechism of the Catholic Church. ${ }^{180}$

The Catechism of the Catholic Church affirms that there is no new public revelation until the second coming of Our Lord. The Church and the Magisterium continue to understand the mystery of revelation guided by the Holy Spirit. Thus, one discovers a profound continuity in Benedict's theology on revelation. His Christocentric approach invites the universal Church to encounter Christ ever anew - also in Scripture.

\section{e) Porta Fidei}

Porta fidei was an apostolic letter in which Benedict announced the "Year of Faith" (October 11, 2012 to November 24, 2013). The Year of Faith corresponded with the fiftieth anniversary of the opening of the Second Vatican Council and the twentieth anniversary of the publication of the Catechism of the Catholic Church. The purpose of the year was to arouse among the faithful the desire to profess the faith with conviction. Benedict invited the faithful to "rediscover the journey of faith so as to shed ever clearer light on the joy and renewed enthusiasm of the encounter with Christ." 181

In this letter Benedict again exhorts the faithful to convert to Christ, the Savior of the world. He points out the Christian mystery in Christ's fullness of revelation:

The Year of Faith is a summons to an authentic and renewed conversion to the Lord, the one Savior of the world. In the mystery of his death and resurrection, God has revealed in its fullness the Love that saves and calls us to conversion of life through the forgiveness of sins. ${ }^{182}$

God revealed himself in Jesus Christ, the savior of the world and the revealer of God's will. Benedict invites the faithful to focus their gaze on Christ - the "Pioneer and Perfecter of faith." 183 By taking on human form in the world and

\footnotetext{
180 "The Christian economy, therefore, since it is the new and definitive Covenant, will never pass away; and no new public revelation is to be expected before the glorious manifestation of our Lord Jesus Christ. Yet, even if revelation is already complete, it has not been made completely explicit; it remains for Christian faith gradually to grasp its full significance over the course of the centuries." Catechism of the Catholic Church, Washington, DC, 2000², art. 66.

${ }^{181}$ Benedict XVI, Apostolic Letter: Porta fidei. art. 2. http://www.vatican.va/.../hf_ben-xvi_ motu-proprio_20111011_porta-fidei_en.ht [accessed: October 2, 2014].

182 Ibid., art. 6.

${ }^{183}$ Ibid., arts. 6, 13.
} 
sharing our weakness, Jesus Christ transforms the whole of humanity. Benedict goes on to reflect on different aspects of faith in Christian life by citing the faith of Mary, the apostles, disciples, and martyrs in history.

\section{Conclusion}

The "encounter with Christ" is a recurring Leitmotif in Benedict's entire opus. His unbroken, consistent line of thought in understanding the concept of revelation as being ultimately the person of Jesus Christ is much in evidence. Jesus Christ is the mediator and the revealer of the Father in the fullest sense a thought that finds its origin in Scripture and tradition: "In all things he himself might be preeminent" (Col 1:18). Christ's primacy over the Old Testament prophets, in the revelation of God, is a fundamental belief of every Christian. Benedict learned from the theology of Bonaventure: revelation is dynamic, personal and progressive in its nature. Bonaventure's study decisively informed Ratzinger's contribution to Dei Verbum. Benedict employs a Christocentric approach to understanding the concept of revelation, which he adopted from Bonaventure, who preached the centrality and finality of salvation history in Christ: "Christ is the head of the body, the Church. He is the beginning, the firstborn from the dead, that in all things he himself might be preeminent" (Col 1:18).

Benedict XVI has a theological tone akin to Augustine, the Victorines, Bonaventure, Newman and Guardini. As a young theologian, he studied the theology of Augustine. Thus he became familiar with the Fathers of the Church. He approached the Middle Ages by dedicating his second major work to Bonaventure's theology. He wrote The Theology of History in St. Bonaventure for his post-doctoral dissertation. In this study, Ratzinger attempted to understand the concept of revelation from Bonaventure's Collations on the Six Days of Creation, which are Bonaventure's formal series of sermons preached to his fellow Franciscan friars.

Ratzinger appreciated that for Bonaventure, revelation in the Hexaëmeron is the spiritual understanding of the Scripture; this understanding comes from "manifold divine wisdom" granted by divine grace, to those who are humble and holy. ${ }^{184}$ Manifold wisdom includes the allegorical, the anagogical, and the tropological interpretation of Scripture. The spiritual understanding of Scripture is dynamic and continues until the second coming of the Lord. Ratzinger also noted the shift that other thirteenth-century theologians made in understanding Scripture. They considered Scripture as revelation, while Bonaventure considered the personal apprehension and appropriation of Scripture as revelation. Ratzinger further developed this thought with a Christocentric approach at the Second Vatican Council and contributed decisively to the final form of Dei Verbum.

\footnotetext{
${ }^{184}$ J. Ratzinger, The Theology of History in St. Bonaventure, 59.
} 
Ratzinger decisively clarified: Scripture and tradition witness to and mediate revelation. They do not contain the fullness of revelation. Scripture and tradition are mediated in human, historical ways. Revelation is dynamic in its nature. Christ is present in Scripture, in the Church, and in the world. His revelation is not confined just to Scripture and tradition but supersedes both, as they are cast in human words and manners. Hence Benedict gives much importance to Christ the Logos, who is the fullness of Revelation.

His post-conciliar writings, including his papal encyclicals, demonstrate his unbroken line of thought on the concept of revelation: in Introduction to Christianity, the three volumes of Jesus of Nazareth, and his other papal writings.

In his book Introduction to Christianity Ratzinger reflects on the creed and retrieves the treasures of the Christian faith. He argues that Jesus' death on the cross is the center of revelation. The uniqueness of Jesus' revelation is that he is the Son of God and the eternal Logos. Christ's revelation supersedes that of all other revelations in the history of salvation. Benedict's love for Christ and the Church motivated him to present Jesus Christ to the world through his three volumes of Jesus of Nazareth. In all three volumes, Benedict argued that Jesus is the face of the Father.

Benedict's encyclicals and other papal writings invite the reader to have a personal relationship with Christ. "Encountering Christ" is the phrase that pervades all of his texts. In this light Benedict XVI's Christocentric approach offers a fresh and deeper understanding of the concept of revelation. Benedict prioritizes Christ the Logos over Scripture and tradition.

May one venture conclude: Ratzinger's/Pope Benedict XVI's lasting legacy is to state vigorously revelation in Christ as the definitive, personal self-disclosure of the Triune God - and thereby also as the identity of the human being. It is as addressees of God's revelation that human beings experience themselves as persons in the full sense. Due to the signal, epochal alienation from natural revelation (intimating the existence of something divine) by virtue of the advances of technology and the positive sciences, a return to a pre-critical (Kantian) naïveté is not possible. Only by believing in a God revealing Himself as a Thou - as prophetically taught by Dei Verbum and Ratzinger/Benedict XVI - can humankind retain and enrich her personhood.

\footnotetext{
Abstract

The article discusses Pope Benedict XVI's / Joseph Ratzinger's understanding of revelation. It shows the bases for his understanding to be found in the theology of St. Bonaventure, more specifically in the Doctor Seraphicus' Hexaëmeron. It is on the theology of history in Bonaventure that Ratzinger had written his terminal paper. This will allow him to impact Vatican II in an original way. The essay describes how the young peritus Joseph Ratzinger contributed in a most decisive
} 
way to the dogmatic constitution on divine revelation Dei Verbum's recalibration of the nature of revelation. It also discusses hope Pope Benedict's teaching office thematized revelation. Revelation is ultimately neither Scripture nor tradition, but the self-disclosure of the Triune God in the Thou of Jesus Christ.

\section{Keywords}

Benedict XVI, Joseph Ratzinger, Jesus Christ, revelation, personalism, thou, Bonaventure, II. Vatican Council, Inspiration, Scripture, tradition, Christocentric, Old Testament, New Testament, Dionysius the Pseudo-Areopagite, Deus Caritas Est, Spe Salvi, Caritas in Veritate, Verbum Domini, Porta Fidei, Augustine, Josef Frings, Ottaviani, Geiselmann, Martin Luther, encounter

\section{Słowa kluczowe}

Benedykt XVI, Józef Ratzinger, Jezus Chrystus, objawienie, personalizm, Bonawentura, Sobór Watykański II, natchnienie, Pisma, Tradycja, chrystocentryzm, Stary Testament, Nowy Testament, Pseudo-Dionizy Areopagita, Deus caritas est, Spe salvi, Caritas in veritate, Verbum Domini, Porta fidei, Augustyn, Józef Frings, Ottaviani, Geiselmann, Marcin Luther, spotkanie

\section{Bibliography}

Anderson C., A Call to Piety: St. Bonaventure's Collations on the Six Days, Quincy [USA, Illinois]: Franciscan Press.

Benedict XVI, Encyclical Letter: Caritas in veritate. art.1. http://www.vatican.va/.../ hf_ben-Xvi_enc_20090629_caritas-in-veritate_en.html [accessed: October 2, 2014].

Benedict XVI, Encyclical Letter: Deus caritas est. art. 1. http://www.vatican.va/.../ hf_ben_xvi_enc_20051225_deus-caritas-est_en.html_accessed: October 2, 2014].

Benedict XVI, Apostolic Letter: Porta fidei. art. 2. http://www.vatican.va/.../hf_benxvi_motu-proprio_20111011_porta-fidei_en.ht [accessed: October 2, 2014].

Benedict XVI, Encyclical Letter: Spe salvi. art. 3. http://www.vatican.va/holy.../hf_benxvi_enc_20071130_spe-salvi_en.html [accessed: October 2, 2014].

Benedict XVI, Post-Synodal Exhortation: Verbum Domini. http://www.vatican.va/.../ hf_be_xvi_exh_20100930_verbum-domini_en.html [accessed: October 2, 2014].

Benedict XVI, St. Paul, San Francisco: Ignatius Press, 2009.

Boeve L., Revelation, Scripture, and Tradition: Lessons from Vatican II's Constitution Dei verbum for Contemporary Theology, "International Journal of Systematic Theology" 13 (October, 2011): 419.

Catechism of the Catholic Church, Washington, DC: Libreria Editrice Vaticana - United States Conference of Catholic Bishop, 2000².

Gaál de E., The Theologian Joseph Ratzinger at Vatican II: His Theological Vision and Role, "Lateranum", LXXVIII/3 (2012), 515-548.

Gaál de E., The Theology of Pope Benedict XVI, New York: Palgrave Macmillan, 2010.

Lateran Council, DH 806.

Latourelle R., Theology of Revelation, Staten Island [USA, New York]: Alba House, 1966.

Matera F.J., God's Saving Grace: A Pauline Theology, Grand Rapids [USA, Michigan]: William B. Eerdmans Publishing Company, 2012. 
New Catholic Encyclopedia, Washington, DC: The Catholic University of America, 2003. Pseudo-Dionysius, Pseudo-Dionysius: the complete Work, trans. Luibheid Colm, New York: Paulist Press, 1987.

Rahner K., Ratzinger J., Revelation and Tradition, New York: Herder and Herder, 1966.

Ratzinger J., Behold the Pierced One, trans. G. Harrison, San Francisco: Ignatius Press, 1986.

Ratzinger J., God's Word: Scripture - Tradition - Office, trans. H. Taylor, ed. P. Hünermann and Th. Söding, San Francisco: Ignatius Press, 2008.

Ratzinger J., Introduction to Christianity, trans. J.R. Foster, San Francisco: Ignatius Press, 2004.

Ratzinger J., Milestones Memories 1927-1977, trans. E. Leiva-Merikakis, San Francisco 2003.

Ratzinger J., Milestones: Memoirs 1927-1977, trans. E. Leiva-Merikakis, San Francisco: Ignatius Press, 1997.

Ratzinger J., On the Way to Jesus Christ, trans. M.J. Miller, San Francisco: Ignatius Press, 2005.

Ratzinger J., Pope Benedict XVI, Jesus of Nazareth: From the Baptism in the Jordan to the Transfiguration, trans. A.J. Walker, New York: Doubleday, 2007.

Ratzinger J., Pope Benedict XVI, Jesus of Nazareth: The Infancy Narratives, trans. Ph.J. Whitmore, New York: Image, 2012.

Ratzinger J., The Theology of History in St. Bonaventure, trans. Z. Hayes, Chicago [USA, Illinois] Franciscan Herald Press, 1971.

Ratzinger J., Theological Highlights of Vatican II, trans. by The Missionary Society of St. Paul the Apostle in the State of New York, New York: Paulist Press, 1966.

Schutz R. and Thurian M., Revelation: A Protestant View, New York: Newman Press, 1968.

Tanner N.P., Decree of the Ecumenical Councils, Vol. 2, Trent to Vatican II, London: Sheed \& Ward, 1990.

Tavard G.H., Dogmatic Constitution on Divine Revelation of Vatican Council II, Glen Rock [USA, New York]: Paulist Press, 1966.

The Confessions: Saint Augustine, ed. J.E. Rotelle, with an introduction, translation, and notes by M. Boulding, New York: New City Press, 2005.

Vincent Twomey D., Pope Benedict XVI: The Conscience of Our Age: A Theological Portrait, San Francisco: Ignatius Press, 2007. 